\title{
What Can the Brunei Government Do to Encourage Halal Logistics Adoption: Lessons from the Literature
}

\author{
Mohamed Syazwan Ab Talib \\ UBD School of Business and Economics, Universiti Brunei Darussalam \\ Bandar Seri Begawan, Brunei Darussalam \\ Email: syazwan.talib@ubd.edu.bn (Corresponding Author) \\ Li Li Pang \\ UBD School of Business and Economics, Universiti Brunei Darussalam \\ Bandar Seri Begawan, Brunei Darussalam \\ Email: lili.pang@ubd.edu.bn \\ Nur Atiqah Md Said \\ UBD School of Business and Economics, Universiti Brunei Darussalam \\ Bandar Seri Begawan, Brunei Darussalam \\ Email:20h1025@ubd.edu.bn
}

\begin{abstract}
The role of government in developing a country's logistics industry is undeniable. Initiatives undertaken by governments have been significant in encouraging the implementation of various logistics service adoption and innovation. Few studies have investigated the role of government in any systematic way - particularly in the adoption of halal logistics. Hence, the purpose of this paper is to determine the measures that the Brunei government could undertake in encouraging halal logistics (HLog) adoption in the country. Using content and narrative analyses of extant logistics management literature that discussed governmental initiatives revealed six measures in the form of regulation, fiscal support, infrastructure and assets, education and research, liberalisation, and exhortation. These measures could be undertaken by the Brunei government to encourage HLog adoption. This paper is among the first to consolidate the measures that could encourage HLog adoption and the very few that reflect on Brunei context.
\end{abstract}

Keywords: logistics management, halal logistics, halal supply chain management, halal industry, government, institutional factor

\section{INTRODUCTION}

In the current economy, religion has become an important issue. Although often overlooked, the interrelation between religion and contemporary management and economic research is undeniable (Tracey, 2012; Mayoral and Esteban, 2019). There is a growing body of literature that acknowledges the presence of religion in the modern business disciplines such as in banking (Sun et al., 2012), tourism (Fourie et al., 2015), human resource (Alewell and Rastetter, 2020), marketing (Casidy, 2014), and even logistics management (Tieman, 2013). Thus, for organisations to compete and sustain in the global markets, the influence of religion should not be underestimated (Butt et al., 2017).

Focusing on logistics management, the fusion with religion, specifically Islam, is commonly known as halal logistics (HLog). As the name suggests, HLog is a combination of the halal principles and logistics knowledge. The term 'halal' means 'permissible' in English. Though normally associated with the consumption of food permitted in the Islamic law, halal is truly universal, applies on all facets of society, and a wholesome lifestyle choice (Bergeaud-Blackler, 2016; Alzeer et al., 2018; Haleem et al., 2020). In recent years, the halal knowledge has been closely studied with food safety domains (Kohilavani et al., 2013; Alzeer et al., 2018) - not to specifically conform to a specific belief but solely on the pursue of basic human need for clean and healthy food. Logistics, on the other hand, is the extensive network of activities, responsibilities, and coordination of product or service movement along the supply chain (Ballou, 2007). Taken together, HLog is the careful planning and distribution of halal-certified goods and services flow from origin to the end that generally abides by the Islamic principles. This definition is close to that of Tieman (2013, p. 5) who define HLog as "the process of managing the procurement, movement, storage and handling of materials, parts, livestock, semi-finished or finished inventory both food and non-food, and related information and documentation flow through the organisation and the supply chain in compliance with the general principles [Islamic law]".

To further showcase the permeations of halal tenet in modern logistics, scholars (Haleem et al., 2020; Mostafa, 2020) demonstrate that HLog is among the prevalent and growing research domains, paralleled with the thriving 
global halal industry. The joint growth between the global halal industry and HLog is obvious considering the rising consumer awareness on the logistical aspects of halal products and services (Tieman et al., 2013; Fathi et al., 2016) and the commitment of logistics companies to offer halalcertified services (Karia and Asaari, 2016; Zailani et al., 2017).

Furthermore, governments across the world capitalise on the massive and lucrative potentials of the halal industry (Othman et al., 2016; Haleem and Khan, 2017; Yousaf and Xiucheng, 2018). The ongoing efforts to develop and promote HLog not only from private firms' initiatives (Tieman and van Nistelrooy, 2014; Zailani et al., 2017; Karia, 2019) but also the push from governments (Talib and Hamid, 2014; Haleem and Khan, 2017; Zulfakar et al., 2018) are encouraging. For instance, the Malaysian government is fully committed to becoming a leading HLog hub and has invested substantially in funding, infrastructure, and legislations (Muhammad et al., 2009; Talib and Hamid, 2014). Similarly, through the Australian Government Authorised Halal Program (AGAHP), the federal government ensures an uncompromised halal meat logistics chains despite it not having control over religious rulings (Zulfakar et al., 2018). Here, halal is more closely associated with food safety than a religious obligation. Moreover, according to Lestari et al. (2018), the central government's policies and regulations on halal matters strengthen the commitment to implement HLog in Indonesia.

Despite numerous governments' initiatives to develop the HLog sector and encourage logistics firms to implement HLog services, efforts remain unknown in Brunei Darussalam (henceforth, Brunei). It seems possible to imply that the lack of research that scrutinises Brunei's logistics sector is a likely reason. Gupta et al. (2011) explain that logistics research on smaller Southeast Asian countries, for instance, Brunei, is limited as the sector is not fully developed. Additionally, Tongzon (2011) argues that data on Brunei's logistics sector is unavailable because there is hardly any research done. Another reason could be drawn from Yean's (2018) observation that Brunei's logistics sector is uncompetitive, disintegrated, and with weak private sector involvement.

Even with these shortcomings, there are signs of progress for the HLog sector in Brunei. According to Tieman (2011), Brunei has one of the most developed halal supply chains in the world after Malaysia. The recognition reflects that the country has a robust, sensitive, and protective HLog chain. However, even though the work by Talib (2020) suggests that HLog in Brunei is developing at a moderate pace, the role of government in promoting the sector's growth is rather terse and abstract. Talib (2020) further argues that despite the government's efforts to grow the country's halal industry, the focus is heavily emphasised on the halal food and tourism sectors and overlooked the fundamental and vital role of HLog. Given the disparity of views, it appears that there is uncertainty on the actual landscape of the logistics sector in Brunei. Collectively, it is with a sound presumption that:

a) There is a paucity of logistics research in Brunei context,

b) There is an ambiguity on the state of HLog in Brunei, and c) The government's efforts in promoting HLog remain unexplored.

Drawing upon these issues, it exposes a gap in the HLog literature and offers a potential area for research. Hence, the objective of this paper is to determine the measures that the Brunei government can undertake to encourage HLog adoption in the country. In line with the objective, the paper will gather evidence from other countries that have been successful in implementing HLog and of those that have well-established logistics industries. This 'lessons learn' approach is appropriate considering the limited extant literature on Brunei's HLog, or its logistics sector in general. Besides, benchmarking and mimicking the best practices from other countries or organisation is common in the halal industry (Talib et al., 2016a)

The present research explores, for the first time, the probable roles the Brunei government could attempt to encourage HLog adoption in the country. It provides an important opportunity to inform the government of the various strategies to develop the HLog sector and simultaneously leverage the growing halal economy. Moreover, this study provides a renewed insight for the government to develop relevant policy measures that could encourage HLog adoption as the currently available policies are more suited for the country's halal food and tourism sectors. Additionally, this work is among the very few that consolidate the proper institutional measures that could encourage HLog adoption, particularly one that reflects on Brunei context. Therefore, the paper could set a platform for future works that concerns not only HLog in Brunei but also the roles of governments in developing the halal industry further.

\section{HALAL INDUSTRY IN BRUNEI}

Brunei is an Islamic monarchy and has a total population of 459,500 in 2019 (Department of Economic Planning and Statistics, DEPS, 2020). The country's halal industry only started in the last 15 years after the government's Ninth National Development Plan (NDP) (2007-2012) recognised the need to establish a premium Brunei Halal brand and provided funds for its development. The brand is one of the government's strategies in diversifying the country's economy from its heavy reliance on petroleum resources and introduces Brunei products to the international market (DEPD, 2008). To date, the progress of its halal industry is encouraging. The Brunei halal sector contributed about B $\$ 103$ million to the country's revenues in 2017 (Kon, 2018). According to Dinar Standard's 2019/2020 State of the Global Islamic Economy Report, Brunei is now ranked tenth of the top fifteen Islamic economies out of 57 economies of Muslim majority countries.

Being a small but resource-rich country, Brunei has been importing most of its food products from neighbouring countries. Food outputs account less than $1 \%$ of the country's GDP, and the food product is the third-largest import constituting about $10 \%$ of total import, valued at $\mathrm{B} \$ 143.6$ million (DEPD, 2019). It is still comparatively cheaper for the government to import food from neighbouring countries, due to its strong currency. Nevertheless, the government has been promoting the agricultural sector to ensure selfsufficiency in food production. Depleting petroleum resources as well as vulnerabilities of the petroleum prices as 
seen at the height of the Asian Financial Crisis of 2007-2008 and the shocking drop in petroleum prices due to the recent coronavirus pandemic globally, disrupts the international supply chains. These circumstances highlight the importance of having a vibrant locally grown food production for food security, and these excesses can provide spinoff to other activities in Halal industries in Brunei.

Brunei introduced the Halal Certificate and Halal Label Order (HCHLO) in 2005, although Halal Meat Act, Chapter 183 was passed since 1999. By 2007, Standard for Halal Food PBD 24:2007 was introduced, and ten years later, an amendment to the HCHLO in 2017 made it compulsory for all food and beverages producers/suppliers (non-halal restaurants are exempted) to obtain the halal certification. In order to promote local halal industries in the country, the government has led several multi-million-dollar initiatives in the halal sector. The Brunei Halal brand, owned by the government's Warifah Holdings gave Ghanim International Corporation the right to grant its logo to businesses which seek its certification (Muhamad et al., 2019). Brunei's first pharmaceutical manufacturing company, a joint venture with Canadian Viva Pharmaceutical, set up a US\$26 million manufacturing plant in Brunei since 2013. In 2017, a partnership with Turkish Marsa's company, a US\$36 million margarine plant was set up to cater for local consumption and international export. Additionally, in the same year, a UAEbased Saahtian Group launched a subsidiary in Brunei to manufacture Halal ready-to-eat meals where $85 \%$ of the products are for export. Moreover, efforts are also underway to build fish farms to grow Atlantic salmon and barramundi in Brunei with Singapore companies while Golden Corporation, a joint venture with a Taiwanese firm, has been producing seafood since 2012.

All the efforts by the Brunei government are gaining momentum toward achieving vibrant and competitive halal industries that could help diversify the country's economy. The outlook is possible as productivity has improved across various sectors in Brunei in recent time. With improved productivity, Brunei can see more exports of its products, as envisioned in the ninth NDP. Nevertheless, with increasing productivity and better visibility in Brunei Halal branding, (Muhamad et al., 2019) the logistics side of the supply chain must not be ignored as it can provide more markets for Brunei made products. The logistical aspect is critical for the protection of halal supply chain integrity and strengthens the halal value chain (Tieman, 2013; Karia and Asaari, 2016). However, several issues surround the halal logistics sector in Brunei, but there is room for improvements (Talib, 2020). Thus, in the effort to reap the benefit of the lucrative global halal industry, and simultaneously boosts Brunei's halal sector, support from the government is imperative. Several precedents from other countries highlighted in the next section emphasise that the backing from the government in logistics is imperative.

\section{GOVERNMENTS IN LOGISTICS RESEARCH}

Governments around the world invest a considerable amount of resources in strengthening the logistics industries irrespective of location, size, or population of a country. The dedication is mainly to encourage economic growth as the logistics industry create job opportunities (Rivera et al., 2014). Admittedly, firms depend on the government for both the physical and nonphysical support. Physical support from the government includes the provision of logistics infrastructure and capital assistance (Banomyong et al., 2015; Hafezalkotob et al., 2015; Jhawar et al., 2017; Li et al., 2020) whereas legislative and policy enforcements are examples of nonphysical support (Rivera et al., 2014; Ekici et al., 2016; Li et al., 2020; Ahlqvist et al., 2020). The synergy between government and logistics firms is manifest and extant literature ratifies the governmental forces in logistics research.

The role of government is evident in numerous logistics research. In humanitarian logistics, Kunz and Reiner (2012) argue that government factor is frequently observed, and the meta-analysis confirms the pivotal role of governments in relief logistics. Additionally, in a recent study on reverse logistics, Govindan and Bouzon (2018) explain that the commitment to carry out reverse logistics operation is prompted by governmental reasons such as to legitimise business or compelled by regulatory obligation. Likewise, scholars (Witkowski and Kiba-Janiak, 2014; Kiba-Janiak, 2016; Neghabadi et al., 2019) in the field of urban logistics substantiate the role of government in devising legislation and policy measures to govern the mobility, liveability, and sustainability of urban areas. Equally, Ren et al. (2020) and Jalil (2018) maintain that the presence of government efforts through regulation, policymaking and economic support is vital, particularly given the growing focus on green and sustainable logistics adoption.

On a macro perspective, the governmental factor in logistics research can also be traced in numerous countries. In the UK, Ramanathan et al. (2014) demonstrate that support from the government encourages logistics firms to apply new technologies. Ramanathan et al. further argue that the greater the level of governmental support, the higher the rate of technology adoption. Similarly, in the US, Rivera et al. (2014) explain that government plays a crucial role in the growth of the country's logistics clusters especially in driving economic development and as a means of employment. Evidence can also be drawn from China where the central government's regulations and policies on environmental preservation shape how logistics companies execute sustainable operations (Ye et al., 2013; Li et al., 2020). Likewise, the various investments set by the Indian government contribute to the overall improvement of India's logistics system (Jhawar et al., 2017). Moreover, in HLog, the substantial support from the federal government in terms of financial incentives, tax reduction, and training are among the reasons behind Malaysia's impressive standing in the HLog sector (Talib and Hamid, 2014; Rashid and Bojei, 2020).

Based on the various examples, governmental roles and status in extant logistics research are apparent. However, despite the palpable precedents, there is little evidence of government initiative being applied in Brunei settings. Accordingly, the deficiency calls for an investigation on the potentials initiatives that the Brunei government can attempt to encourage logistics companies to implement HLog operation. Thereby, a review of the literature is an 
appropriate approach to scrutinise relevant extant logistics literature as it is a suitable way to understand what is known and reveal what is unknown (Zimmermann et al., 2016) about the governmental initiatives in HLog. Hence, the next section explains the paper materials and methods for reviewing extant logistics literature.

\section{REVIEW MATERIALS AND METHODS}

Establishing the likely measures that the Brunei Government may take to support the adoption of HLog services in the country requires a proper review of the literature. According to Seuring and Gold (2012), reviewing the extant literature is a fundamental and critical part of any research. Besides, a literature review allows for the formulation and reaffirmation of the subject under study and identifies gaps in the disciplines, which provides the basis for further research (Seuring and Gold, 2012; Zimmermann et al., 2016). Although literature-based research is a qualitative approach where reliability and validity may be contentious (Seuring and Gold, 2012), it is widely applied in logistics research (Sachan and Datta, 2005). Recent application of the literature review approach in logistics and supply chain research can be found in reverse logistics (Banihashemi et al., 2019), green supply chain (Tseng et al., 2019), humanitarian logistics (Banomyong et al., 2019) and also halal supply chain (Haleem et al., 2020). These instances reflect the fact that the literature review approach is contemporary and widely applied in the field of logistics research and therefore justifies the current paper's methodology.

This review paper applies a three-step process to review the relevant existing logistic literature that may have a bearing on the adoption of HLog services in Brunei. First, the search for review materials was carried out by collecting journal articles published in scholarly journals. Specifically, articles were sourced from the International Journal of Logistics Management (IJLM), International Journal of Physical Distribution \& Logistics Management (IJPDLM), Journal of Business Logistics (JBL), Journal of Operations Management (JOM), Journal of Supply Chain Management (JSCM), and Transportation Research Part E (TRE). The journals were chosen because they are the leading journals in the field of logistics research (Carter et al., 2009). Additionally, articles were also sourced from the Journal of Islamic Marketing (JIMA). This was done to enrich the review further and remain consistent with the specified theme, the HLog. Besides, JIMA is a leading journal that specialises in halal business-related research (Haleem et al., 2020), including HLog. The Web of Science database (www.webofknowledge.com) was used to search and retrieve the relevant journal articles. This database was selected for its better content coverage and quality than other prominent databases (Adriaanse and Rensleigh, 2013). Further, the search terms were limited to "Logistics Management", "Supply Chain Management", and
"Government". The term "Supply Chain Management" was considered because it often used interchangeably with "Logistics Management" (Overstreet et al., 2011). In further narrowing the search scope, only English-language journal articles published between 2010 and 2019 were included. This excludes other forms of publications (i.e. conference proceedings, book chapters, book series, editorials), limits contents in other languages, and remains recent within the last decade. The first step gathered a total of 102 journal articles.

Second, the gathered articles were then analysed. A content analysis approach was conducted to extract the quantitative aspects of the selected journal articles (Seuring and Gold, 2012). Here, the quantitative contents from the articles were categorised according to the (a) year of publication, (b) number of papers from selected journals, (c) country of study, and (d) field of study. The rationales behind the need to highlight the quantitative categories were to portray that:

a) the governmental factor has been a recurring trend in recent and relevant logistic research,

b) governmental factor studies have been well-considered in reputable logistic journals,

c) the presence of the governmental factor has been evident in logistic sectors involving many countries, and

d) governmental elements have been examined in various fields in logistic.

The second step omitted 13 articles on the basis that the papers did not fit the scope of the review. As a result, 89 relevant articles have been identified. These papers discussed governmental factors in logistic research, either explicitly or implicitly. The authors then read and examine the selected 89 papers.

The qualitative aspects of the selected articles were observed in the third and last steps. Specifically, this step was assigned to highlight the government measures that could be apparent or latent. The qualitative approach was consistent with that of Seuring and Gold (2012, p. 546) who explained that a qualitative means of a literature review is to examine the "latent content excavated [that require] interpretation of the underlying meaning of terms and arguments". A narrative analysis technique was used to extract the essence of government measures. Again, as a qualitative approach, a narrative review may be contestable (Tranfield, 2003), but such a measure could still provide valuable insights and richer arguments (Trautrims et al., 2012). Moreover, logistics research needs narrative approach research despite the dominance of quantitative approaches (Trautrims et al., 2012; Jafari, 2015).

Figure 1 shows the steps in the literature review process. Having explained the methodology for the review, the next section reports on the findings of the quantitative review. Subsequently, the findings of the qualitative review, which relate to the government measures, are presented in the later section. 


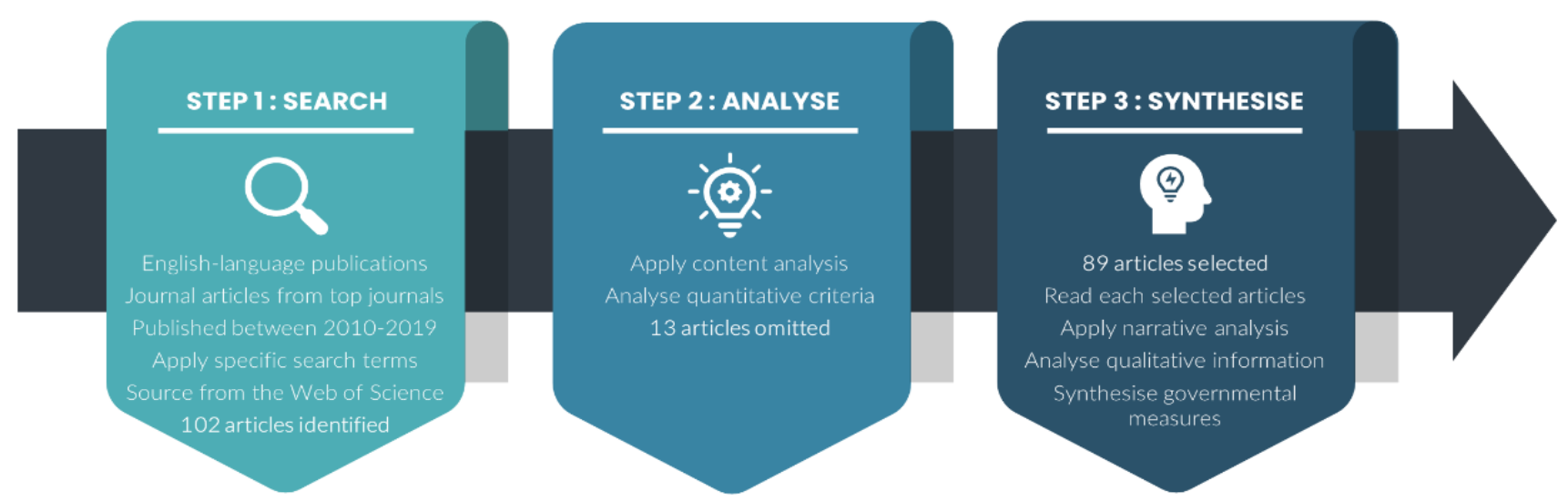

Figure 1 Three-steps Literature Review Process

\section{QUANTITATIVE REVIEW FINDINGS}

Based on the analysis of the content, this section reveals the findings of the review. Four key findings of the quantitative review, namely the year of publications, the number of articles from selected journals, the location of the studies, and the fields of study, will be presented and explained accordingly. The complete findings from the review are shown in Appendix 1.

\subsection{Year of Publications}

Logistics research, which studied the government factor, has shown a consistent occurrence over the last decade. As shown in Figure 2, the largest number of publications was recorded in 2018 with 18 papers, followed by the years 2019 (14 papers), 2017 (12 papers) and 2013 (11 papers). Fewer publications, however, were written in 2011 (3 papers), 2012 (3 papers) and 2014 (4 papers). A closer look at Figure 2 shows that more than half of the articles have been published in the last five years. The steady presence of the government subject in logistic research in the last decade underpins the ever-influential role of the government in the field. This is probably because the government is generally seen as a dominant force and has a coercive influence on the logistics industry (Cai et al., 2010; Bhakoo and Choi, 2013Zulfakar et al., 2018). This might suggest that the Brunei government's involvement in encouraging HLog in the country is not unusual and is expected as other governments have been doing for more than a decade.
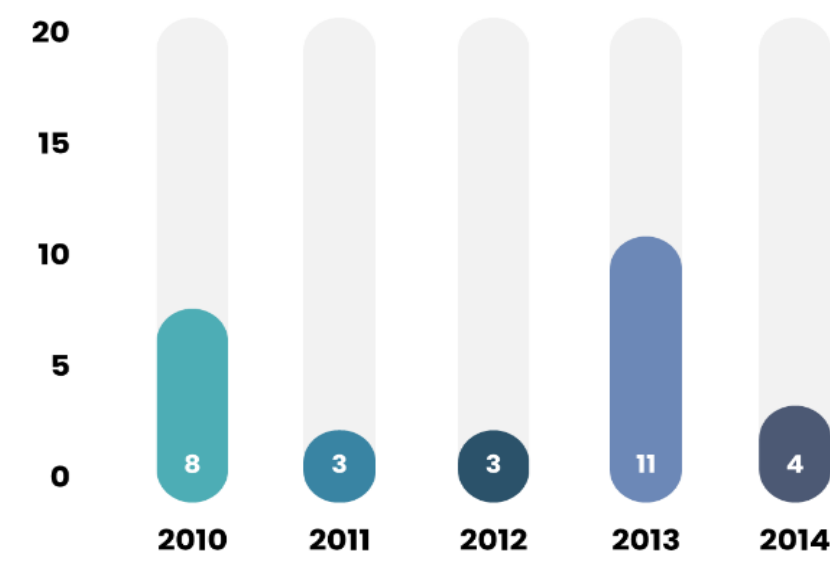
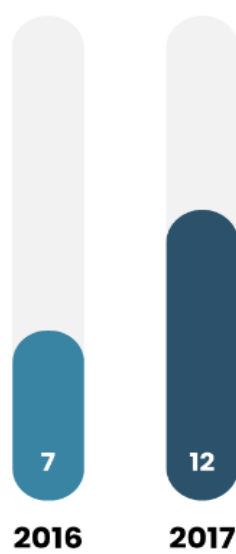

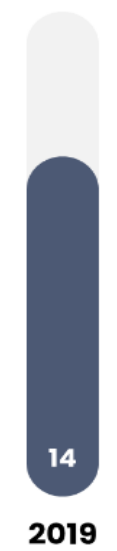

Figure 2 Yearly Number of Publication (2010-2019)

\subsection{Articles from Selected Journals}

The review of major journals confirms that government factor studies have been well-considered in the field of logistics. The number of articles in selected journals is shown in Figure 3. The TRE has the largest number of papers with 27 articles, while $J B L$ and $J S C M$ have recorded the least number of publications with seven articles each. Additionally, the JIMA also reported a reasonable number of
HLog articles. This corroborates the state-of-the-art assessment by Haleem et al. (2020) that JIMA is a leading source for halal academic research. Collectively, the findings of this review appear to be consistent with other literature review papers (Sachan and Datta, 2005; Carter et al., 2009; Seuring and Gold, 2012; Zimmermann et al., 2016) which found that high-quality logistics research is often derived from the specified journals. It is also worth noting that, 
despite the prevalence of governmental factor reported in major logistics journals, there is no special issue that focuses on the institutional factor in logistics and that there is yet an exclusive edition of HLog. Perhaps journal editors could be persuaded to call for a special issue on HLog, and institutional focus could be one of the areas of interest.

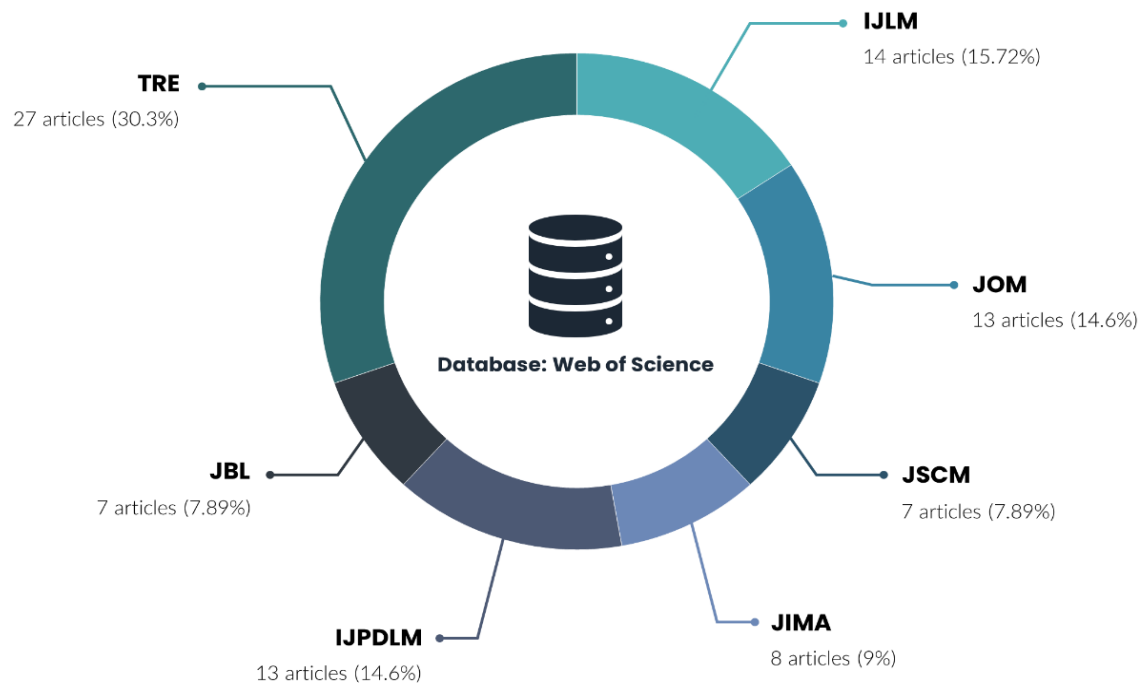

Figure 3 Number and Percentage of Articles Published in Main Journals

\subsection{Country of Studies}

Figure 4 highlights the number of publications from 22 different countries around the world. This proves that the involvement of governments in the logistics industry affects many countries. There are, however, 19 articles that did not specify any country; probably because they dealt with mathematical modelling or simulations. From the review, the two largest number of studies are conducted in China and the US, each with 14 papers. The review is consistent with the Zimmermann et al. (2016) study that the dominance of the US and China in logistics research is evident. Additionally, seven articles carried out studies on three or more countries, while the remaining countries reported between one and four studies. Together, this review on the country of study reaffirms that governmental element in logistics research is of global interest. Focusing on HLog research, even though much of the studies were conducted in Malaysia (Haleem et al., 2020), it is reassuring that HLog studies have been undertaken by scholars from non-Muslim countries such as Australia (Zulfakar et al., 2018) and South Korea (Bashir et al., 2019). Perhaps that governments and businesses in other countries have begun to realise the enormous potentials and opportunities of the global halal industry. This could, therefore, be a good indicator for the Brunei government to encourage the adoption of HLog in the country and that it may be beneficial to learn from other countries, for instance, Malaysia.

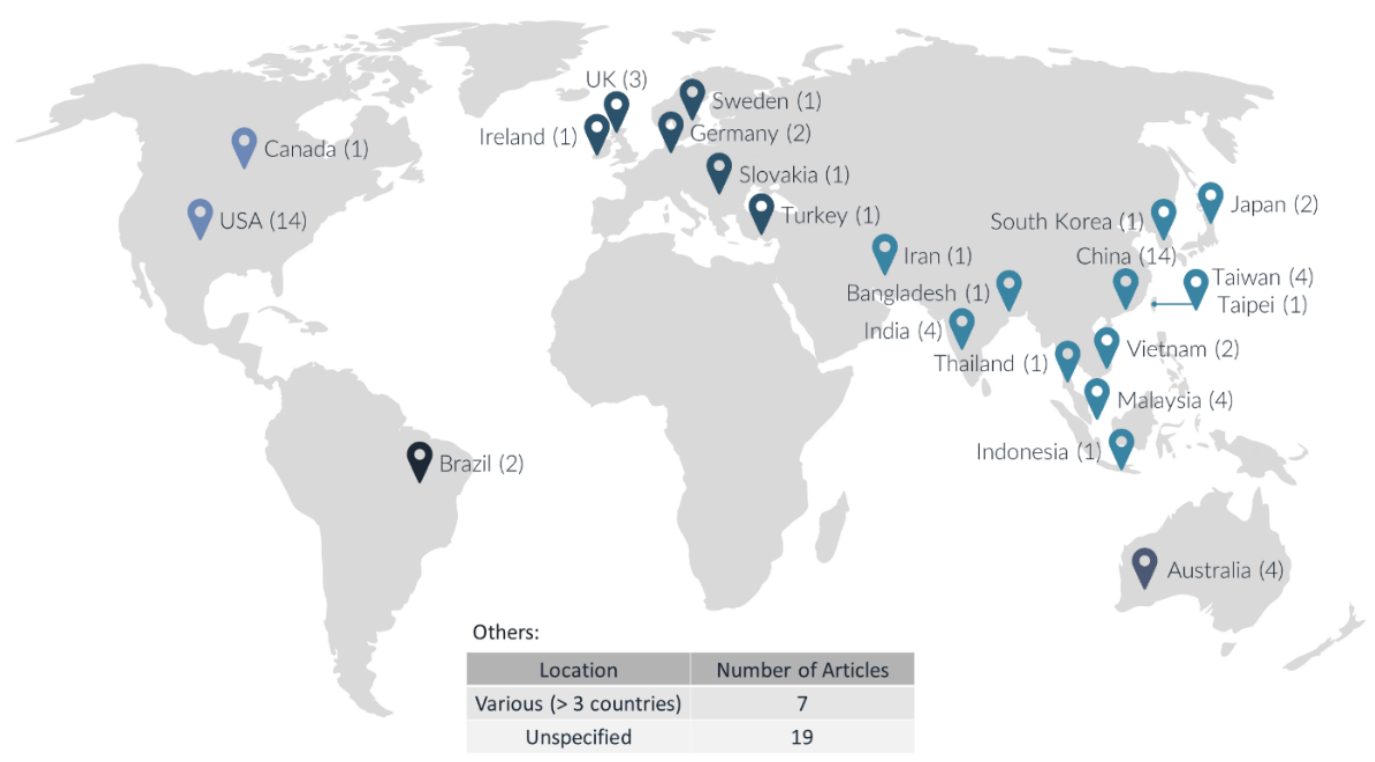

Figure 4 Country of Studies 


\subsection{Fields of Study}

From the 89 selected articles, logistics research that studies the elements of government can be found in a variety of fields. The fields studied are listed in Appendix 1 and presented in the form of a word cloud in Figure 5. Variation in font sizes indicates the frequency of the fields studied in the selected articles. Larger font means that a field is often studied, and vice versa. By observing the word cloud, readers could see the prevalent fields of logistics research that considered the elements of government. Besides, it would allow scholars and practitioners to get the essence of the content, specifically by tracing prominent and less prominent fields of study. As shown in Figure 5, the "supply chain" and "logistics" are among the prevailing contents. Understandably, and as mentioned earlier, these terms are identical to one another (Overstreet et al., 2011). It is therefore evident that relief supply chain (Sheu, 2011, 2016; Paul and Wang, 2015; Dube et al., 2016; Dubey et al., 2018; Acar and Kaya, 2019), environmental/sustainable supply chain (McKinnon, 2010a; Hall and Matos, 2010; Ehrgott et al., 2013; Sirilertsuwan et al., 2018), cross-border logistics (Hausman et al., 2010; Davis and Friske, 2013; Grainger and Morini, 2019), and halal logistics (Talib and Hamid, 2014; Ngah et al., 2015; Zailani et al., 2017) are the regularly studied fields.
Moreover, words such as public-private, partnership, and governance reflect the fact that institutional elements are constantly being studied in the field of logistics. These justify the fact that public-private partnership (PPP) is widely practised by governments around the world, most notably on investment in logistics infrastructures (Kang et al., 2012, 2013; Li and Cai, 2017; Lu and Meng, 2017). Likewise, the involvement of government in the logistics sector is increasingly important in improving coordination, cooperation and security in the logistics chains (Bai et al., 2016; Jacobs and Singhal, 2017; Tokar and Swink, 2019). Taken together, the results of the review in this section signify that the governmental elements have been well examined in various fields of logistic research. The review, therefore, provides the Brunei Government with a lesson that its support for the halal industry should include other subsectors, not just halal food and tourism. This also means that the governance of the halal supply chain must always be observed and that investments in the form of PPP could encourage the development of the HLog infrastructure in the country as HLog's dedicated assets are largely limited (Talib, 2020).

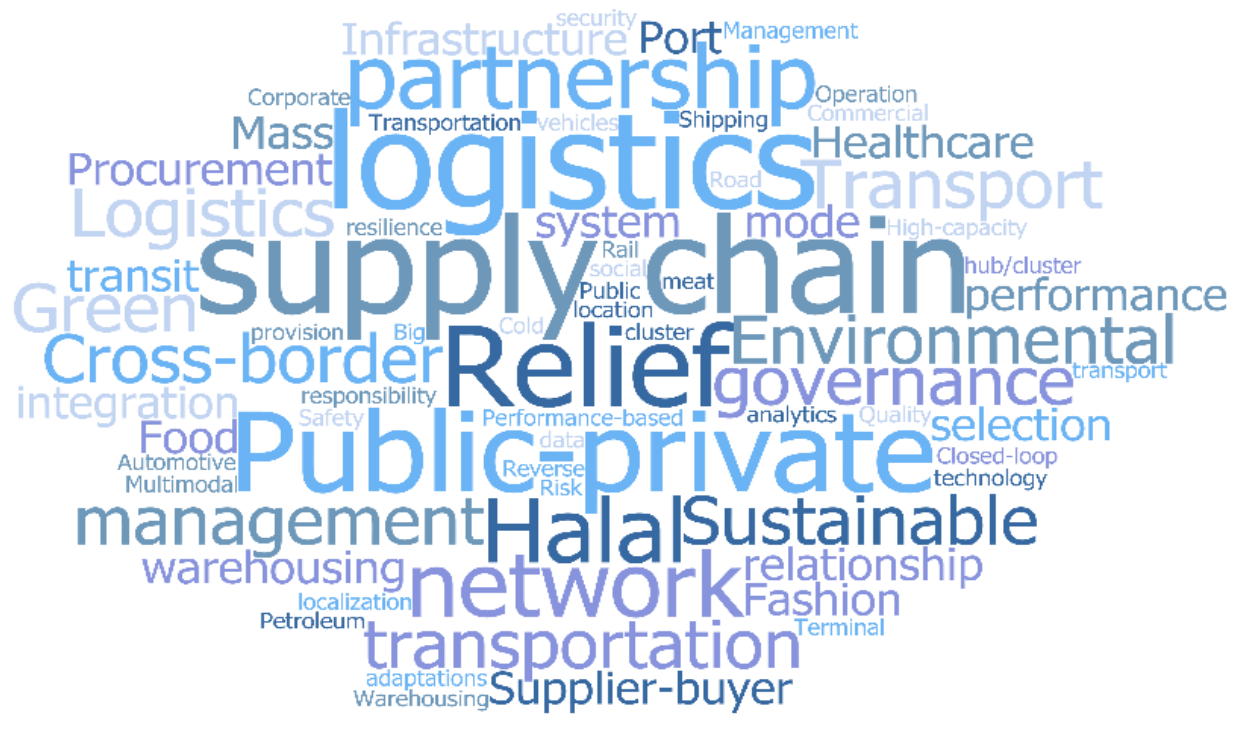

Figure 5 Field of Studies

\section{DISCUSSION: WHAT CAN THE GOVERNMENT DO?}

The literature review found that there are six potential measures that the Brunei government could attempt to encourage the adoption of HLog. The measures are generally categorised into regulation, fiscal support, infrastructure and assets, education and research, liberalisation, and exhortation. These measures shall be discussed accordingly.

\subsection{Regulation}

Governments typically govern by implementing laws and regulations that extend to supply chain parties and society at large. Government regulatory efforts on HLog are crucial, while aggressive promotion and proactive actions are encouraged (Ngah et al., 2015). According to Ngah et al. (2015), the external pressure from the government in encouraging more logistics companies to provide HLog services is imperative because the push is more compelling compared to internal organizational push. Despite the apparent role of the government, regulatory efforts are more geared towards halal products, largely food products, and Talib et al. (2015) suggest that similar attention should also be paid to the regulation and promotion of the HLog service as well. As a result, the regulations could force logistics companies to engage in halal operations and turn HLog into 
industry-standard operating procedures, particularly when halal business is a national agenda (Talib et al., 2015).

The regulatory measures from governments in the logistics industry are evident (Wu et al., 2014; Bajec et al., 2015; Wang and Chang, 2016; Harland et al., 2019), particularly through the establishment of a range of halal industry standards (Talib and Hamid, 2014; Zailani et al., 2017). For example, the Malaysian government is applauded for developing a series of halal standards, beginning with the highly referred Malaysian Standard for Halal Food Processing, Preparation, Handling and Storage, (MS1500) and the world's first dedicated standard for HLog operation, the Halal Supply Chain Management System Standard (MS2400). Other governments, such as by the Indonesian government, introduces the Halal Assurance System (HAS 23000) while the UAE with its Emirates Standards and Metrology Authority (ESMA).

Taking Brunei into perspective, similar suggestions could be made. Brunei has yet to have its own halaldedicated logistic standards, but attempts are underway (Talib, 2020). Perhaps the measure should be accelerated, given the importance of HLog to the country's high dependency on halal food imports. However, in order to prevent regulatory requirements problems, the implementation should be carried out with caution. This is because the existing HLog regulatory requirements are voluntary and logistics firms are known to be reluctant to adopt HLog; and voiced costs and collaboration as the common barriers (Talib and Hamid, 2014; Talib et al., 2015; Zailani et al., 2017). To overcome this, perhaps the Brunei government could make HLog a decree, given that halal practices are well embodied in the national philosophy of Melayu Islam Beraja (Malay Islamic Monarchy in English) and that doing so could lead to greater market opportunities (Zailani et al., 2017).

\subsection{Fiscal Report}

Governmental measures to encourage HLog adoption can be in the form of fiscal support. This task is a means of institutional support through fiscal stimulus or monetary benefits provided to businesses engaged in HLog operations. A synthesis of the review reveals that governmental financial support might be through monetary funding or investments (Min and Ahn, 2017; Spring et al., 2017), grant allocation (Bhakoo and Choi, 2013; Spring et al., 2017), subsidy schemes (Li and Cai, 2017; Tong et al., 2018; Kundu and Sheu, 2019), or tax incentives (Hall and Matos, 200; Guerrero et al., 2013; Choi and Luo, 2019). According to Min and Ahn (2017), capital funding from the state government is an integral source of funding for the mass transit system in the US. Similarly, in Australia, Bhakoo and Choi (2013) identified that hospitals received a grant from the state government to upgrade supply chain information systems. Likewise, Li and Chai (2017) conclude that government incentive of allocating subsidies could potentially encourage PPP investments. Meanwhile, the recent work of Choi and Luo (2019) tax exception arrangement could be a productive measure to encourage sustainable operation and presents a mutually beneficial outcome for supply chain members.

In HLog, similar fiscal support is also evident. The Malaysian government, for instance, provide direct monetary funds and grant allocations to encourage for halalcertified businesses in the country (Rashid and Bojei, 2020). Moreover, the Malaysian government has eased its tax levies allowing tax exemption for a limited period to enable more companies to engage in halal operations. Besides, tax incentives offered by governments would have a positive impact, such as encouraging more HLog services or potentially improving logistics performance (Talib et al., 2016 b). In research on strategising international market penetration for Korean companies, Bashir et al. (2019) recommend that related financial support through subsidies and tax reduction are very much needed.

Therefore, the Brunei government should also be emphatic in financially supporting the development of HLog and encourage businesses in the country to practice HLog operations. Currently, fiscal support is heavily channelled on developing entrepreneurial capacity (Talib, 2020), but support should be equally distributed to facilitate HLog adoption. Drawing lessons from the review, given that the majority of halal companies are small and medium-sized enterprises (Zailani et al., 2017) and that logistics infrastructure and facilities require large capital investments (Ngah et al., 2015), government financial assistance is needed to kick-start HLog operations and service offerings. However, firms should not exploit the government financial assistance and must not be perceived as being overly reliant on the public sector. Rather, government financial support should be observed as a policy tool that can encourage HLog adoption, develop the halal industry, and generate the economy.

\subsection{Infrastructure and Assets}

One of the many functions of the government is to provide adequate, reliable and sustainable logistical infrastructure and assets. Governments are known to be providers of logistics infrastructure and assets because they have the economic capacity, resources, and financial instruments to build and operate capital-intensive structures such as ports, transport hubs and systems. The findings of the review accentuate the role of the government in promoting and facilitating the logistics industry. For instance, in relief and humanitarian logistics, Acimovic and Goentzel (2016) reveal that government-owned support depots are often used to store disaster relief inventories and supplies. Likewise, Heaslip and Kovacs (2019) point out that, in addition to funding support, government involvement could also be traced to the provision of key resources during humanitarian aid, and that government assets are used to transport manpower and distribution of relief to and from disaster sites. Moreover, Bolumole et al. (2015) explain in the development of cluster logistics that the use of governmentowned infrastructure could strengthen regional capabilities and the performance of logistics hubs. According to Rivera et al. (2014), apart from tax and regulatory support, US industrial clusters rely on the government to provide effective infrastructures that would allow the industry to grow.

Government support through publicly run infrastructure such as seaports or warehouses may encourage more logistics firms to implement HLog. This is because building and operating infrastructure costs are substantial (Ngah et al., 2015). While providing government 
infrastructure is necessary, it is not encouraged and sustainable for logistics companies to be depending solely on the government. Hence, a PPP is desirable to overcome this. Partnerships between the government of Malaysia and MASkargo and Malaysia Airport, for example, are an excellent example of PPP. MASkargo, a cargo division for the government-linked company (GLC), Malaysia Airlines, is certified halal thus allowing it to provide HLog services, thereby opening broader market opportunities (Rahman et al., 2018). This exemplifies that the establishment of HLog infrastructure, along with strong government support, are among the main reasons behind Malaysia's leading role in the HLog sector (Talib and Hamid, 2014). The analysis presented in this section, therefore, reaffirms the critical support from the government in promoting HLog through the provision of infrastructural and asset provisions.

According to Tieman et al. (2012), HLog infrastructures help facilitate the import and export movements of halal commodities. In addition, halal dedicated infrastructure can extend halal integrity, prevent cross-contamination, and integration of HLog assets can positively influence logistics performance (Ngah et al., 2015; Karia, 2019). In Brunei, the country has adequate and reasonable logistics infrastructures. According to Talib (2020), major terminals such as the Brunei International Airport and the Muara Seaport have undergone considerable upgrades in recent years. Talib argues, however, that infrastructure and assets specific to HLog operations remain scarce. Evidently, government involvement in providing logistics infrastructures is obvious. Currently, its major airport is solely owned and operated by the government, while the main seaport is a PPP between Darussalam Assets (GLC) and the Guangxi Beibu Gulf Port Group from China. In addition, the Brunei-Guangxi Economic Corridor (BGEC), a joint bilateral project, is aimed at developing the logistics sector of the country (Hamdan and Hoon, 2019). These projects and initiatives by the Brunei government are undoubtedly encouraging, but as the country aspires to be a leading country in the halal industry, dedicated HLog infrastructures and assets are of paramount importance.

\subsection{Education and Research}

Ensuring the continuous development and quality of talent delivery through dedicated educational institutions or recognised training programs is another measure highlighted in the review. Studies (Bhakoo and Choi, 2013; Chang and Wu, 2015; Spring et al., 2017; Gligor and Nguyen, 2018; Gualandris and Klassen, 2018) show that human capital development through sound education, training and research is fundamental to the progress of the logistics industry. It has been argued by scholars such as Gligor and Nguyen (2018) that there is a real need for appropriate and rigorous government-funded training to overcome the lack of trained logistics personnel. In the UK, financial support and incentives in the form of government-subsidized training are offered across supply chain organisations (Spring et al., 2017).

Similarly, in HLog, the review highlights that institutional support through structured education is pertinent. According to Talib and Hamid (2014), the Malaysian government's support for the provision of sound education through the country's higher education institutions and research centres is exemplary. This measure not only ensures good quality education but also ensures the availability of future HLog professionals. However, more efforts should be made. Rahman et al. (2018) propose that the government or its appointed agencies be more dynamic in providing HLog-related training, especially to logistics companies. Moreover, encouragement from the government to promote HLog training should not only focus on major logistics clusters but should also encompass an entire nation (Ngah et al., 2015). This would allow training to reach more logistics companies and ultimately encourage more HLog adoption. In South Korea, although research and training are extensive, Bashir et al. (2019) critique that the contents are not halal-specific and that courses are run by nongovernmental organisations. More structured and halalcentric training programs offered by the government could entice more companies to participate and could potentially lead to halal service adoption.

Reflecting on the lessons learned from the literature review, the Brunei government could establish several policy measures to overcome the pressing need for HLog trained workforce. In line with the recommendation by Talib (2020), more government initiatives are needed because the currently available experts are more in the halal food and legislative domains, but hardly any in HLog. Hence, initiatives such as provision for education allowances, scholarships, or subsidised HLog programs should, therefore, be considered. Plus, the promotion of HLog-related programs among education providers in the higher learning institutions through the provision of relevant teaching and learning materials is encouraged.

\subsection{Liberalisation}

Liberalisation, the process of removing, reducing, or relaxing government restriction, has long been practised in the logistics sector (McKinnon, 2010b). The World Trade Organisation (n.d.) states that liberalisation has a positive impact on the economy that has fundamentally benefited industrial demand and societal needs. A recent study by Tokar and Swink (2019) describe how regulatory enforcement by the government is crucial is the logistics chain, and that service liberalisation has severely impacted public policy and how the industry operates. Moreover, the reduction in trade barriers in Europe and the deregulation and privatisation in the UK revitalise the industry and create competitive edges for companies for decades (Spring et al., 2017). Evidently, the liberalisation of the logistics sector allows for fairer competition between organisations and encourages greater operational efficiency (Adiputranto et al., 2018). Similarly, the lesser constraint frees the government from budgetary obligation and, in some cases, enable it to operate efficiently and make the industry more competitive (Harrod, 2013; Niu and Zhang, 2013).

Furthermore, in the halal sector, where private firms heavily dominant (Bergeaud-Blackler, 2016), there are traces of measures in which the government has begun to reduce its presence. While such removal is partial and mainly on the marketing and promotion purposes, this does not mean the same for certification and standardisation matters as these crucial aspects are still well under the control and purview of 
some governments (i.e. Malaysia and Brunei). For example, the Malaysian government established the HDC in 2006 to promote and facilitate the country's halal ecosystem (Talib and Hamid, 2014). Meanwhile, in Brunei, Ghanim International Corporation was formed in 2009 to promote the brand of bruneihalalfoods and to assists companies and investors in the supply chain process (Miskam et al., 2018). However, the approach to the liberalisation of services in the logistics sector in Brunei has yet to be implemented. This is supported by Yean (2018) that liberalisation of services in Brunei is still lacking in the transportation and logistics sector compared with other ASEAN countries, but efforts are underway (Tongzon, 2011). Lessons for the Brunei government could be drawn from the study by Yean (2018) that the liberalisation of logistics services could be achieved by providing investment incentives for innovative services, which, in this case, HLog, would ultimately contribute to the economic development of the country.

\subsection{Exhortation}

Government is known to dictate an advocacy role. The review suggests that the advocating function could be classified into encouragement or demanding role. Under this premise, the term "exhortation" is appropriate as it envelops both the encouragement and demanding roles. This paper argues that the government should be a focal point for industry reference, foster transnational or crossorganizational collaborations, encourage best practices, or become a force of encouragement for the industry. Exhortative measures by the government can be traced prevalently in the literature. For example, Sheu (2011) demonstrates that the Taiwanese government's urge has led to the implementation of green supply chain practices. More recently, Dobrzykowski (2019) concludes that the government's strong coercive regulatory push could be a motivator or inhibitor of US health supply chain coordination. The hindering factor is expected if the government exhortative approach overlooks the vital synergy between service implementation and regulatory support (Bhakoo and Choi, 2013).

Based on the review, establishing a centralised agency overseeing the HLog sector, encouraging business matching and partnerships with local or overseas firms, or implementing intergovernmental schemes and strategies, are among the governmental actions to guide and encourage the
HLog adoption (Talib and Hamid, 2014; Talib et al., 2015; Zailani et al., 2017; Zulfakar et al., 2018; Rahman et al., 2018). As demonstrated by the proactive measures taken by the Malaysian government to establish the Halal Development Corporation (HDC), a GLC that promotes and encourages the development of the halal ecosystem in the country (Talib and Hamid, 2014; Rahman et al., 2018). Another example could be drawn from the Australian government (Zulfakar et al., 2018). According to Zulfakar et $a l$., the coercive force from the federal government through the establishment of the AGAHP has, in a way, encouraged the HLog chain in the country. This is a good example of an exhortative attempt by a government, even though it has no absolute control regarding matters of religions. Through government-backed initiatives, firms will be more motivated to deliver HLog operations. A reasonable explanation is that government involvement could demonstrate that the HLog venture is significant and sustainable, thereby instilling a sense of trust among firms. That is why the government's exhortative measures might prompt HLog's adoption.

From the review, a similar measure could be undertaken by the Brunei government. As the country is known for its close adherence to the Islamic teachings, perhaps the government could be the advocate for a complete and rigorous HLog free riba and observe the Islamic finance arrangements. Such an approach is a noble cause and has yet to be implemented by any country or logistics company. To do so, the Brunei government could encourage the total HLog services and exhorts logistics companies to comply. However, the exhortative measure should be implemented with caution and consider the response from the industry's stakeholders.

All the studies reviewed here support the notion that the government is an integral part of the logistics industry. In view of all that has been discussed herein, several ruminations on the potential measures that the Brunei government can take to encourage the adoption of HLog are presented. An illustration shown in Figure 6 depicts that amid the massively lucrative and growing global halal industry, the Brunei government aims to diversify its economy and that the halal sector has been identified as a viable ground to venture. To materialise the objective, the significance of HLog should not be ignored. Therefore, the six pillars represent the suggested feasible measures that should be taken to support the adoption of HLog in the country.

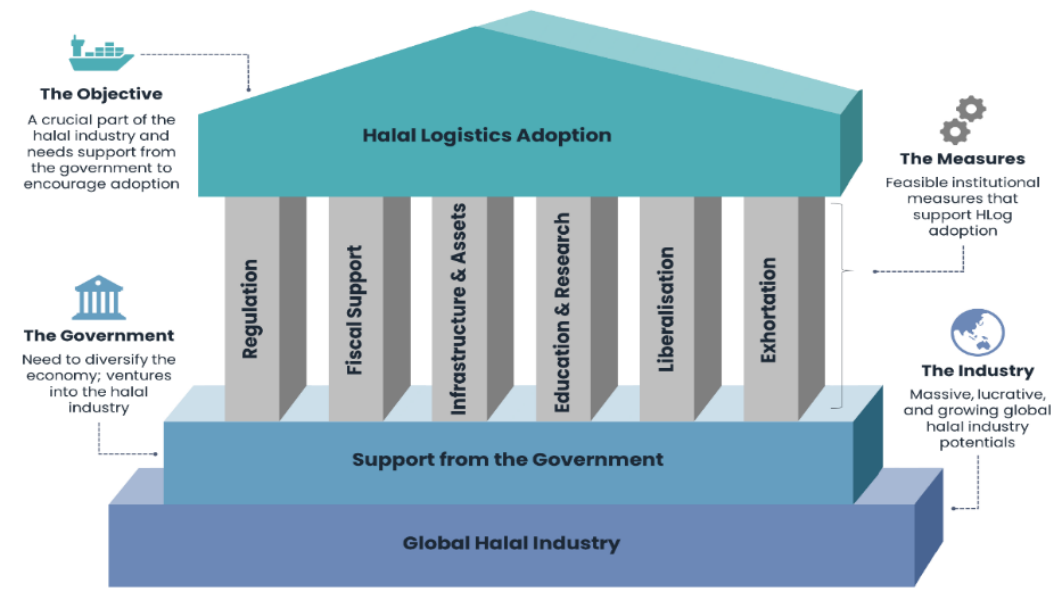

Figure 6 Government Measures to Support Halal Logistics Adoption 


\section{CONCLUSION}

The involvement and influence of governments in the logistics sector are evident. More importantly, the presence of government is particularly needed in order to develop HLog, as this is evident in many countries, such as Malaysia, Australia and South Korea. However, there has been limited studies of HLog in Brunei and scholars have yet to investigate the measures that the government can take to encourage the adoption of HLog in the country. Recognizing the deficiency, this paper sought to identify the measures that the government could take to encourage the adoption of HLog in Brunei. Through a review of the existing logistic literature, which discussed the government element, this paper identified six measures that could be taken by the Brunei government to encourage HLog adoption. The measures identified are regulation, fiscal support, infrastructure and assets, education and research, liberalisation and exhortation.

Support in the form of regulation is through the legislation of appropriate decree and the enforcement of relevant industry standards for HLog. A regulatory approach not only instils a sense of control but also harmonises HLog operations. Next, fiscal support is a means of incentive through fiscal stimulus or monetary support provided to logistics companies that engaged in HLog operations. Capital investments, monetary grants, subsidy provisions, or direct financial injection are examples of financial support measures. Meanwhile, the review suggests that the support from the government could come by way of infrastructural provision. The construction of dedicated HLog facilities, terminals, equipment, and information technology through PPP are the potential institutional support that can be provided by the Brunei government. Another support could be initiated with structured education and governmentbacked training that could result in qualified and highly trained HLog professionals. In addition, the lessons learned from the past logistics literature indicate that the Brunei government could engage in a liberalisation measure by removing, reducing, or relaxing restrictions within the logistics sector. Such a measure could allow healthy industry competitions, achieve efficient operation, and might promote HLog adoption in Brunei. Lastly, the exhortative measure is an advocative role of the government that directly urges, demands, or coerces logistics companies to implement HLog operation.

\subsection{Research Implications}

The paper appears to be among the first to address the lack of logistics research in Brunei's context and the very few that proposes viable measures that the government can attempt to encourage HLog adoption. This study, therefore, could be beneficial to policymakers to device feasible policies, decree, and strategies to encourage more businesses to implement HLog operation. Additionally, logistics managers could use the information contained in this paper to leverage on the various incentives that the government could offer. Besides, the paper reveals the need to train or retrain logistics professionals because doing so could shape a human capital competitive advantage. This review also lays the groundwork for future research in HLog, primarily on the development of the service in Brunei. Scholars could use this study as a platform for future research as the review consolidates and synthesise government-related research in logistics.

\subsection{Limitation and Recommendations for Future Research}

While the review conducted a thorough literature search using the Web of Science database, it should be noted that the reviewed articles used in this paper were limited to predetermined peer-reviewed journals. Although the review thoroughly reviewed each publication and findings are relevant, some useful articles that were contained in other databases, journals, or forms (i.e. conference proceedings, chapters, etc.) might be overlooked. Nevertheless, this offers a room for improvement, and therefore, future research should engage on a more systematic and comprehensive review that might ascertain the measures highlighted in this paper of include additional measures that are not reported here. Besides, being limited to Brunei's perspective, application and generalisation should proceed with caution. As countries differ in size, population, location, culture, and the availability of resources, the measures presented in this paper may or may not be applicable. Therefore, a more universal measure or a multi-country context should be the agenda for future research. Despite being a qualitative piece, findings found in this paper could be useful to set the stage for future empirical or quantitative studies.

\section{REFERENCES}

Acar, M. and Kaya, O. (2019), “A healthcare network design model with mobile hospitals for disaster preparedness: A case study for Istanbul earthquake", Transportation Research Part E: Logistics and Transportation Review, Vol. 130, pp. 273-292.

Acimovic, J. and Goentzel, J. (2016), "Models and metrics to assess humanitarian response capacity", Journal of Operations Management, Vol. 45 No. SI, pp. 11-29.

Adriaanse, L.S. and Rensleigh, C. (2013), "Web of Science, Scopus and Google Scholar", The Electronic Library, Vol. 31 No. 6 , pp. 727-744.

Ahlqvist, V., Norrman, A., \& Jahre, M. (2020). Supply chain risk governance: towards a conceptual multi-level framework. Operations and Supply Chain Management: An International Journal, 13(4), 382-395

Albalate, D. and Bel, G. (2010), "What shapes local public transportation in Europe? Economics, mobility, institutions, and geography", Transportation Research Part E: Logistics and Transportation Review, Vol. 46 No. 5, pp. 775-790.

Alewell, D. and Rastetter, D. (2020), "On the (ir)relevance of religion for human resource management and diversity management: A German perspective", German Journal of Human Resource Management, Vol. 34 No. 1, pp. 9-31.

Alzeer, J., Rieder, U. and Hadeed, K.A. (2018), "Rational and practical aspects of Halal and Tayyib in the context of food safety", Trends in Food Science \& Technology, Vol. 71, pp. 264-267.

Bai, X., Sheng, S. and Li, J.J. (2016), "Contract governance and buyer-supplier conflict: The moderating role of institutions", Journal of Operations Management, Vol. 41, pp. 12-24.

Bajec, P., Tuljak-Suban, D. and Krmac, E. (2015), "Do ISO standards favour logistics provider efficiency, competitiveness and sustainability? A Slovenian perspective", International Journal of Logistics Management, Vol. 26 No. 2, pp. 275-295. 
Ballou, R.H. (2007), "The evolution and future of logistics and supply chain management", European Business Review, Vol. 19 No. 4, pp. 332-348.

Banihashemi, T.A., Fei, J. and Chen, P.S.-L. (2019), "Exploring the relationship between reverse logistics and sustainability performance", Modern Supply Chain Research and Applications, Vol. 1 No. 1, pp. 2-27.

Banomyong, R., Varadejsatitwong, P. and Oloruntoba, R. (2019), "A systematic review of humanitarian operations, humanitarian logistics and humanitarian supply chain performance literature 2005 to 2016", Annals of Operations Research, Vol. 283 No. 1-2, pp. 71-86.

Bashir, K.M.I., Kim, J.-S., Mohibbullah, M., Sohn, J.H. and Choi, J.-S. (2019), "Strategies for improving the competitiveness of Korean seafood companies in the overseas halal food market", Journal of Islamic Marketing, Vol. 10 No. 2, pp. 606-632.

Bergeaud-Blackler, F. (2016), "The Halal Certification Market in Europe and the World: A First Panorama", in BergeaudBlackler, F., Johan, F. and Lever, J. (Eds.), Halal Matters, Routledge, New York, NY, pp. 105-126.

Bhakoo, V. and Choi, T. (2013), "The iron cage exposed: Institutional pressures and heterogeneity across the healthcare supply chain", Journal of Operations Management, Vol. 31 No. 6, SI, pp. 432-449.

Bolumole, Y.A., Closs, D.J. and Rodammer, F.A. (2015), "The Economic Development Role of Regional Logistics Hubs: A Cross-Country Study of Interorganizational Governance Models", Journal of Business Logistics, Vol. 36 No. 2, pp. 182-198.

Butt, M.M., Rose, S., Wilkins, S. and Ul Haq, J. (2017), "MNCs and religious influences in global markets", International Marketing Review, Vol. 34 No. 6, pp. 885-908.

Cai, S., Jun, M. and Yang, Z. (2010), "Implementing supply chain information integration in China: The role of institutional forces and trust", Journal of Operations Management, Vol. 28 No. 3, SI, pp. 257-268.

Cantor, D.E. and Terle, M. (2010), "Applying a voluntary compliance model to a proposed transportation safety regulation", International Journal of Physical Distribution \& Logistics Management, Vol. 40 No. 10, pp. 822-846.

Cantor, D.E., Macdonald, J.R. and Crum, M.R. (2011), "The Influence of Workplace Justice Perceptions on Commercial Driver Turnover Intentions", Journal of Business Logistics, Vol. 32 No. 3, pp. 274-286.

Carter, C.R., Liane Easton, P., Vellenga, D.B. and Allen, B.J. (2009), "Affiliation of Authors in Transportation and Logistics Academic Journals: A Reevaluation”, Transportation Journal, Vol. 48 No. 1, pp. 42-52.

Casidy, R. (2014), "Religion and marketing in the Asia Pacific region", Asia Pacific Journal of Marketing and Logistics, Vol. 26 No. 5, p. APJML-09-2014-0135.

Chang, H.-L. and Wu, J.-G. (2015), "Exploring company ability to meet supply chain security validation criteria", International Journal of Physical Distribution \& Logistics Management, Vol. 45 No. 7, SI, pp. 691-710.

Chen, X. and Wang, X. (2016), "Effects of carbon emission reduction policies on transportation mode selections with stochastic demand", Transportation Research Part E: Logistics and Transportation Review, Vol. 90 No. SI, pp. 196-205.

Choi, T.-M. and Luo, S. (2019), "Data quality challenges for sustainable fashion supply chain operations in emerging markets: Roles of blockchain, government sponsors and environment taxes", Transportation Research Part E: Logistics and Transportation Review, Vol. 131, pp. 139-152.

Davis, D.F. and Friske, W. (2013), "The Role of Public-Private Partnerships in Facilitating Cross-Border Logistics: A Case
Study at the US/Canadian Border", Journal of Business Logistics, Vol. 34 No. 4, pp. 347-359.

Department of Economic Planning and Development (DEPD) (2008), "Brunei Darussalam Long-Term Development Plan; Wawasan Brunei 2035; Outline of Strategies and Policies for Development (OSPD) 2007-217 and National Development Plan 2007-2012", Bandar Seri Begawan, Brunei: Prime Minister's Office.

Department of Economic Planning and Development (DEPD) (2019), "Brunei Darussalam Statistical Yearbook 2018", Bandar Seri Begawan: Ministry of Finance and Economy.

Department of Economic Planning and Statistics (DEPS) (2020), "Report of the Mid-Year Population Estimates 2019", Department of Statistics, DEPS: Ministry of Finance and Economy.

Dobrzykowski, D. (2019), "Understanding the Downstream Healthcare Supply Chain: Unpacking Regulatory and Industry Characteristics", Journal of Supply Chain Management, Vol. 55 No. 2, pp. 26-46.

Dube, N., der Vaart, T., Teunter, R.H. and Van Wassenhove, L.N. (2016), "Host government impact on the logistics performance of international humanitarian organisations", Journal of Operations Management, Vol. 47-48, pp. 44-57.

Dubey, R., Luo, Z., Gunasekaran, A., Akter, S., Hazen, B.T. and Douglas, M.A. (2018), "Big data and predictive analytics in humanitarian supply chains: Enabling visibility and coordination in the presence of swift trust", International Journal of Logistics Management, Vol. 29 No. 2, SI, pp. 485512.

Dwivedi, G., Srivastava, S.K. and Srivastava, R.K. (2017), "Analysis of barriers to implement additive manufacturing technology in the Indian automotive sector", International Journal of Physical Distribution \& Logistics Management, Vol. 47 No. 10, SI, pp. 972-991.

Eckerd, A. and Girth, A.M. (2017), "Designing the Buyer-Supplier Contract for Risk Management: Assessing Complexity and Mission Criticality", Journal of Supply Chain Management, Vol. 53 No. 3, pp. 60-75.

Ehrgott, M., Reimann, F., Kaufmann, L. and Carter, C.R. (2013), "Environmental Development of Emerging Economy Suppliers: Antecedents and Outcomes", Journal of Business Logistics, Vol. 34 No. 2, pp. 131-147.

Fathi, E., Zailani, S., Iranmanesh, M. and Kanapathy, K. (2016), "Drivers of consumers' willingness to pay for halal logistics", British Food Journal, Vol. 118 No. 2, pp. 464479.

Feng, M., Mangan, J. and Lalwani, C. (2012), "Comparing port performance: Western European versus Eastern Asian ports", International Journal of Physical Distribution \& Logistics Management, Vol. 42 No. 5, pp. 490-512.

Fourie, J., Rosselló, J. and Santana-Gallego, M. (2015), "Religion, Religious Diversity and Tourism", Kyklos, Vol. 68 No. 1, pp. 51-64.

Gattiker, T.F. and Carter, C.R. (2010), "Understanding project champions' ability to gain intra-organizational commitment for environmental projects", Journal of Operations Management, Vol. 28 No. 1, pp. 72-85.

Gligor, D., Tan, A. and Nguyen, T.N.T. (2018), "The obstacles to cold chain implementation in developing countries: insights from Vietnam", International Journal of Logistics Management, Vol. 29 No. 3, SI, pp. 942-958.

Goh, S.H. (2019), "Barriers to low-carbon warehousing and the link to carbon abatement A case from emerging Asia", International Journal of Physical Distribution \& Logistics Management, Vol. 49 No. 6, pp. 679-704.

Grainger, A. and Morini, C. (2019), "Disentangling cross-border interactions", International Journal of Logistics Management, Vol. 30 No. 4, pp. 958-973. 
Gualandris, J. and Klassen, R.D. (2018), "Emerging Discourse Incubator: Delivering Transformational Change: Aligning Supply Chains and Stakeholders in Non-Governmental Organizations", Journal of Supply Chain Management, Vol. 54 No. 2, pp. 34-48.

Guerrero, S.E., Madanat, S.M. and Leachman, R.C. (2013), "The Trucking Sector Optimization Model: A tool for predicting carrier and shipper responses to policies aiming to reduce GHG emissions", Transportation Research Part E: Logistics and Transportation Review, Vol. 59, pp. 85-107.

Gupta, S., Goh, M., Desouza, R. and Garg, M. (2011), “Assessing trade friendliness of logistics services in ASEAN", Asia Pacific Journal of Marketing and Logistics, Vol. 23 No. 5, pp. 773-792.

Hafezalkotob, A. (2017), "Competition, cooperation, and coopetition of green supply chains under regulations on energy saving levels", Transportation Research Part E: Logistics and Transportation Review, Vol. 97, pp. 228-250.

Haleem, A. and Khan, M.I. (2017), "Towards successful adoption of Halal logistics and its implications for the stakeholders", British Food Journal, Vol. 119 No. 7, pp. 1592-1605.

Haleem, A., Khan, M.I., Khan, S. and Jami, A.R. (2020), "Research status in Halal: a review and bibliometric analysis", Modern Supply Chain Research and Applications, Vol. 2 No. 1, pp. 23-41.

Hall, J. and Matos, S. (2010), "Incorporating impoverished communities in sustainable supply chains", International Journal of Physical Distribution \& Logistics Management, Vol. 40 No. 1-2, pp. 124-147.

Hamdan, M. and Hoon, C.-Y. (2019), "Brunei Darussalam: Making Strides with a Renewed Focus on the Future", in Singh, D. and Cook, M. (Eds.), Southeast Asian Affairs 2019, Vol. 2019, ISEAS-Yusof Ishak Institute Singapore, Singapore, pp. 85-102.

Harland, C., Telgen, J., Callender, G., Grimm, R. and Patrucco, A. (2019), "Implementing Government Policy in Supply Chains: An International Coproduction Study of Public Procurement", Journal of Supply Chain Management, Vol. 55 No. 2, pp. 6-25.

Harrod, S. (2013), "Auction pricing of network access for North American railways", Transportation Research Part E: Logistics and Transportation Review, Vol. 49 No. 1, pp. 176189.

Hausman, W.H., Lee, H.L., Napier, G.R.F., Thompson, A. and Zheng, Y. (2010), "A Process Analysis of Global Trade Management: An Inductive Approach", Journal of Supply Chain Management, Vol. 46 No. 2, pp. 5-29.

Heaslip, G. and Kovacs, G. (2019), "Examination of service triads in humanitarian logistics", International Journal of Logistics Management, Vol. 30 No. 2, pp. 595-619.

Huang, Y.-C., Rahman, S., Wu, Y.-C.J. and Huang, C.-J. (2015), "Salient task environment, reverse logistics and performance", International Journal of Physical Distribution \& Logistics Management, Vol. 45 No. 9-10, pp. 979-1006.

Jacobs, B.W. and Singhal, V.R. (2017), "The effect of the Rana Plaza disaster on shareholder wealth of retailers: Implications for sourcing strategies and supply chain governance", Journal of Operations Management, Vol. 49-51, pp. 52-66.

Jafari, H. (2015), "Logistics flexibility: a systematic review", International Journal of Productivity and Performance Management, Vol. 64 No. 7, pp. 947-970.

Jalil, A. (2017). Pursuing Sustainability via Reverse Logistics: The Symbiosis Effect Between the Local Authorities and Householders. Operations and Supply Chain Management: An International Journal, 11(1), 26-35.

Kang, C.-C., Feng, C.-M. and Kuo, C.-Y. (2012), "Comparison of royalty methods for build-operate-transfer projects from a negotiation perspective", Transportation Research Part E:
Logistics and Transportation Review, Vol. 48 No. 4, pp. 830 842.

Kang, C.-C., Lee, T.-S. and Huang, S.-C. (2013), "Royalty bargaining in Public-Private Partnership projects: Insights from a theoretic three-stage game auction model", Transportation Research Part E: Logistics and Transportation Review, Vol. 59, pp. 1-14.

Karia, N. (2019), "Halal logistics: practices, integration and performance of logistics service providers", Journal of Islamic Marketing, Vol. ahead-of-p No. ahead-of-print, available at: https://doi.org/10.1108/JIMA-08-2018-0132.

Karia, N. and Asaari, M.H.A.H. (2016), "Halal value creation: its role in adding value and enabling logistics service", Production Planning \& Control, Vol. 27 No. 9, pp. 677-685.

Kon, J. (2018), "Youth Encouraged to Take Up Opportunities in Agriculture Halal Industries", Borneo Bulletin, November $20^{\text {th }}, 2018$.

Kundu, T. and Sheu, J.-B. (2019), "Analyzing the effect of government subsidy on shippers' mode switching behavior in the Belt and Road strategic context", Transportation Research Part E: Logistics and Transportation Review, Vol. 129, pp. 175-202.

Lai, Y., Sun, H. and Ren, J. (2018), "Understanding the determinants of big data analytics (BDA) adoption in logistics and supply chain management: An empirical investigation", International Journal of Logistics Management, Vol. 29 No. 2, SI, pp. 676-703.

Lestari, Y.D., Susanto, J.M., Simatupang, T.M. and Yudoko, G. (2018), "Intention towards halal logistics: a case study of Indonesian consumers", Journal for Global Business Advancement, Vol. 11 No. 1, pp. 22-10.

Levine-Clark, M. and Gil, E.L. (2008), "A Comparative Citation Analysis of Web of Science, Scopus, and Google Scholar", Journal of Business \& Finance Librarianship, Vol. 14 No. 1 , pp. 32-46.

Li, D., Zhao, L., Wang, C., Sun, W. and Xue, J. (2018), "Selection of China's imported grain distribution centers in the context of the Belt and Road initiative", Transportation Research Part E: Logistics and Transportation Review, Vol. 120, pp $16-34$.

Li, S. and Cai, H. (2017), "Government incentive impacts on private investment behaviors under demand uncertainty", Transportation Research Part E: Logistics and Transportation Review, Vol. 101, pp. 115-129.

Li, S., Cai, J., Feng, Z., Xu, Y. and Cai, H. (2019), "Government contracting with monopoly in infrastructure provision: Regulation or deregulation?", Transportation Research Part E: Logistics and Transportation Review, Vol. 122, pp. 506523.

Lu, Z. and Meng, Q. (2017), "Analysis of optimal BOT highway capacity and economic toll adjustment provisions under traffic demand uncertainty", Transportation Research Part E: Logistics and Transportation Review, Vol. 100, pp. 17 37.

Mayoral, L. and Esteban, J. (2019), "Religiosity and Economic Performance: The Role of Personal Liberties", in Rubin, J.P., Carvalho, S. and Iyer, J. (Eds.), Advances in the Economics of Religion, Springer International Publishing, Cham, pp. 405-422.

McKinnon, A. (2010b), "The role of government in promoting green logistics", in McKinnon, A., Cullinane, S., Browne, M. and Whiteing, A. (Eds.), Green Logistics: Improving the Environmental Sustainability of Logistics, 1st ed., Kogan Page, London, pp. 341-360.

McKinnon, A.C. (2010a), "Product-level carbon auditing of supply chains Environmental imperative or wasteful distraction?", International Journal of Physical Distribution \& Logistics Management, Vol. 40 No. 1-2, pp. 42-60. 
Min, H. and Ahn, Y.-H. (2017), "Dynamic Benchmarking of Mass Transit Systems in the United States Using Data Envelopment Analysis and the Malmquist Productivity Index", Journal of Business Logistics, Vol. 38 No. 1, pp. 5573.

Min, H., Ahn, Y.-H. and Lambert, T. (2017), "Benchmarking and improving mass transit systems in the United States based on best-in class practices Policy implications", International Journal of Logistics Management, Vol. 28 No. 1, SI, pp. 172193.

Miskam, S., Hamid, N.A. and Othman, N. (2018), "Halal legal spectrum and certification bodies: Study in Brunei and Thailand", Advanced Science Letters, Vol. 24 No. 7, pp. 5074-5079.

Mittal, N., Agarwal, R. and Selen, W. (2018), "Value creation and the impact of policy interventions: Indian LPG supply chain case study", International Journal of Logistics Management, Vol. 29 No. 1, pp. 64-89.

Mogale, D.G., Kumar, M., Kumar, S.K. and Tiwari, M.K. (2018), "Grain silo location-allocation problem with dwell time for optimization of food grain supply chain network", Transportation Research Part E: Logistics and Transportation Review, Vol. 111, pp. 40-69.

Mostafa, M.M. (2020), "A knowledge domain visualization review of thirty years of halal food research: Themes, trends and knowledge structure", Trends in Food Science \& Technology, Vol. 99, pp. 660-677.

Muhamad, N., Masri, M.H. and Khalid, A.M. (2019), "Brunei Halal certification: A review and way forward", in Fischer, J. and Jammes, J. (Eds.), Muslim Piety as Economy, Routledge, London, UK, pp. 75-96.

Muhammad, N.M.N., Isa, F.M. and Kifli, B.C. (2009), "Positioning Malaysia as halal-hub: Integration role of supply chain strategy and halal assurance system", Asian Social Science, Vol. 5 No. 7, pp. 44-52.

Ngah, A.H., Zainuddin, Y. and Thurasamy, R. (2015), "Barriers and enablers in adopting of halal warehousing", Journal of Islamic Marketing, Vol. 6 No. 3, pp. 354-376.

Nguyen, Q. and Kim, T.H. (2019), "Promoting adoption of management practices from the outside: Insights from a randomized field experiment", Journal of Operations Management, Vol. 65 No. 1, pp. 48-61.

Niu, B. and Zhang, J. (2013), "Price, capacity and concession period decisions of Pareto-efficient BOT contracts with demand uncertainty", Transportation Research Part E: Logistics and Transportation Review, Vol. 53, pp. 1-14.

Niu, B., Chen, L. and Zhang, J. (2017), "Punishing or subsidizing? Regulation analysis of sustainable fashion procurement strategies", Transportation Research Part E: Logistics and Transportation Review, Vol. 107, pp. 81-96.

Othman, B., Shaarani, S.M. and Bahron, A. (2016), "The Potential of ASEAN in Halal Certification Implementation: A Review", Pertanika Journal of Social Sciences and Humanities, Vol. 24 No. 1, pp. 1-24.

Oum, T.H., Pathomsiri, S. and Yoshida, Y. (2013), "Limitations of DEA-based approach and alternative methods in the measurement and comparison of social efficiency across firms in different transport modes: An empirical study in Japan", Transportation Research Part E: Logistics and Transportation Review, Vol. 57 No. SI, pp. 16-26.

Overstreet, R.E., Hall, D., Hanna, J.B. and Kelly Rainer, R. (2011), "Research in humanitarian logistics", Journal of Humanitarian Logistics and Supply Chain Management, Vol. 1 No. 2, pp. 114-131.

Palsson, H., Hiselius, L.W., Wandel, S., Khan, J. and Adell, E. (2017), "Longer and heavier road freight vehicles in Sweden Effects on tonne-and vehicle-kilometres, $\mathrm{CO} 2$ and socioeconomics", International Journal of Physical Distribution \& Logistics Management, Vol. 47 No. 7, SI, pp. 603-622.
Park, H. (Kevin), Chang, Y.-T. and Zou, B. (2018), "Emission control under private port operator duopoly", Transportation Research Part E: Logistics and Transportation Review, Vol. 114, pp. 40-65.

Paul, J.A. and Wang, X. (Jocelyn). (2015), "Robust optimization for United States Department of Agriculture food aid bid allocations", Transportation Research Part E: Logistics and Transportation Review, Vol. 82, pp. 129-146.

Rahman, N.A.A., Mohammad, M.F., Rahim, S.A. and Noh, H.M. (2018), "Implementing air cargo halal warehouse: insight from Malaysia", Journal of Islamic Marketing, Vol. 9 No. 3 , pp. $462-483$

Randall, W.S., Nowicki, D.R. and Hawkins, T.G. (2011), "Explaining the effectiveness of performance-based logistics: a quantitative examination", International Journal of Logistics Management, Vol. 22 No. 3, pp. 324-348.

Rivera, L., Gligor, D. and Sheffi, Y. (2016), "The benefits of logistics clustering", International Journal of Physical Distribution \& Logistics Management, Vol. 46 No. 3, pp. 242-268.

Rotchanakitumnuai, S. (2013), "Assessment of e-procurement auction with a balanced scorecard", International Journal of Physical Distribution \& Logistics Management, Vol. 43 No. 1 , pp. 39-53.

Sachan, A. and Datta, S. (2005), "Review of supply chain management and logistics research", International Journal of Physical Distribution \& Logistics Management, Vol. 35 No. 9, pp. 664-705.

Scholten, K., Scott, P.S. and Fynes, B. (2010), "(Le)agility in humanitarian aid (NGO) supply chains", International Journal of Physical Distribution \& Logistics Management, Vol. 40 No. 8-9, pp. 623-635.

Seuring, S. and Gold, S. (2012), "Conducting content-analysis based literature reviews in supply chain management", edited by Wilding, R.Supply Chain Management: An International Journal, Vol. 17 No. 5, pp. 544-555

Sheu, J.-B. (2011), "Bargaining framework for competitive green supply chains under governmental financial intervention", Transportation Research Part E: Logistics and Transportation Review, Vol. 47 No. 5, pp. 573-592.

Sheu, J.-B. (2016), "Supplier hoarding, government intervention, and timing for post-disaster crop supply chain recovery", Transportation Research Part E: Logistics and Transportation Review, Vol. 90 No. SI, pp. 134-160.

Sirilertsuwan, P., Ekwall, D. and Hjelmgren, D. (2018), "Proximity manufacturing for enhancing clothing supply chain sustainability", International Journal of Logistics Management, Vol. 29 No. 4, SI, pp. 1346-1378.

Song, M., Chen, M. and Wang, S. (2018), "Global supply chain integration, financing restrictions, and green innovation: Analysis based on 222,773 samples", International Journal of Logistics Management, Vol. 29 No. 2, SI, pp. 539-554.

Spring, M., Hughes, A., Mason, K. and McCaffrey, P. (2017), "Creating the competitive edge: A new relationship between operations management and industrial policy", Journal of Operations Management, Vol. 49-51, pp. 6-19.

Srivastava, S.K., Chaudhuri, A. and Srivastava, R.K. (2015), "Propagation of risks and their impact on performance in fresh food retail", International Journal of Logistics Management, Vol. 26 No. 3, pp. 568-602

Storer, M., Hyland, P., Ferrer, M., Santa, R. and Griffiths, A. (2014), "Strategic supply chain management factors influencing agribusiness innovation utilization", International Journal of Logistics Management, Vol. 25 No. 3, pp. 487-521.

Sun, S., Goh, T., Fam, K., Xue, Y. and Xue, Y. (2012), “The influence of religion on Islamic mobile phone banking services adoption", Journal of Islamic Marketing, Vol. 3 No. 1 , pp. 81-98. 
Swanson, R.D. and Smith, R.J. (2013), "A Path to a Public-Private Partnership: Commercial Logistics Concepts Applied to Disaster Response", Journal of Business Logistics, Vol. 34 No. 4, pp. 335-346.

Talib, M.S.A. (2020), "Halal Logistics in Brunei: Current Constraints and Future Potentials", Journal of Emerging Economies and Islamic Research, Vol. 8 No. 1, pp. 69-76.

Talib, M.S.A. and Hamid, A.B.A. (2014), "Halal logistics in Malaysia: a SWOT analysis", Journal of Islamic Marketing, Vol. 5 No. 3, pp. 322-343.

Talib, M.S.A. and Hamid, A.B.A. (2014), "Halal logistics in Malaysia: a SWOT analysis", Journal of Islamic Marketing, Vol. 5 No. 3, pp. 322-343.

Talib, M.S.A., Hamid, A.B.A. and Thoo, A.C. (2016b), "Can halal certification influence logistics performance?", Journal of Islamic Marketing, Vol. 7 No. 4, pp. 461-475.

Talib, M.S.A., Hamid, A.B.A. and Zulfakar, M.H. (2015), "Halal supply chain critical success factors: a literature review", Journal of Islamic Marketing, Vol. 6 No. 1, pp. 44-71.

Talib, M.S.A., Sawari, S.S.M., Hamid, A.B.A. and Thoo, A.C. (2016a), "Emerging Halal food market: An Institutional Theory of Halal certificate implementation", Management Research Review, Vol. 39 No. 9, pp. 987-997.

Tan, Z. (2012), "Capacity and toll choice of an add-on toll road under various ownership regimes", Transportation Research Part E: Logistics and Transportation Review, Vol. 48 No. 6, pp. 1080-1092.

Tieman, M. (2011), "The application of Halal in supply chain management: in-depth interviews", Journal of Islamic Marketing, Vol. 2 No. 2, pp. 186-195.

Tieman, M. (2013), "Establishing the Principles In Halal Logistics", Journal of Emerging Economies and Islamic Research, Vol. 1 No. 1, pp. 1-13.

Tieman, M. and van Nistelrooy, M. (2014), "Perception of Malaysian Food Manufacturers Toward Halal Logistics", Journal of International Food \& Agribusiness Marketing, Vol. 26 No. 3, pp. 218-233.

Tieman, M., Che Ghazali, M. and van der Vorst, J.G.A.J. (2013), "Consumer perception on halal meat logistics", British Food Journal, Vol. 115 No. 8, pp. 1112-1129.

Tokar, T. and Swink, M. (2019), "Public Policy and Supply Chain Management: Using Shared Foundational Principles to Improve Formulation, Implementation, and Evaluation", Journal of Supply Chain Management, Vol. 55 No. 2, pp. 6879.

Tong, X., Lai, K., Zhu, Q., Zhao, S., Chen, J. and Cheng, T.C.E. (2018), "Multinational enterprise buyers' choices for extending corporate social responsibility practices to suppliers in emerging countries: A multi-method study", Journal of Operations Management, Vol. 63 No. SI, pp. 2543.

Tongzon, J. (2011), "Liberalisation of logistics services: the case of ASEAN", International Journal of Logistics Research and Applications, Vol. 14 No. 1, pp. 11-34.

Tracey, P. (2012), "Religion and Organization: A Critical Review of Current Trends and Future Directions", The Academy of Management Annals, Vol. 6 No. 1, pp. 87-134.

Tranfield, D., Denyer, D. and Smart, P. (2003), "Towards a Methodology for Developing Evidence-Informed Management Knowledge by Means of Systematic Review", British Journal of Management, Vol. 14 No. 3, pp. 207-222.

Trautrims, A., Grant, D.B., Cunliffe, A.L. and Wong, C. (2012), "Using the 'documentary method' to analyse qualitative data in logistics research", edited by Flint, D.International Journal of Physical Distribution \& Logistics Management, Vol. 42 No. 8/9, pp. 828-842.

Tseng, M.-L., Islam, M.S., Karia, N., Fauzi, F.A. and Afrin, S. (2019), "A literature review on green supply chain management: Trends and future challenges", Resources, Conservation and Recycling, Vol. 141, pp. 145-162.

Tu, N., Adiputranto, D., Fu, X. and Li, Z.-C. (2018), "Shipping network design in a growth market: The case of Indonesia", Transportation Research Part E: Logistics and Transportation Review, Vol. 117 No. SI, pp. 108-125.

Voss, M.D. and Williams, Z. (2013), "Public-Private Partnerships and Supply Chain Security: C-TPAT as an Indicator of Relational Security", Journal of Business Logistics, Vol. 34 No. 4, pp. 320-334.

Wang, J.J., Li, J.J. and Chang, J. (2016), "Product co-development in an emerging market: The role of buyer supplier compatibility and institutional environment", Journal of Operations Management, Vol. 46 No. SI, pp. 69-83.

Wang, S., Liu, F., Lian, L., Hong, Y. and Chen, H. (2018), "Integrated post-disaster medical assistance team scheduling and relief supply distribution", International Journal of Logistics Management, Vol. 29 No. 4, SI, pp. 1279-1305.

Wang, W., Yang, S., Xu, L. and Yang, X. (2019), "Carrot/stick mechanisms for collection responsibility sharing in multi-tier closed-loop supply chain management", Transportation Research Part E: Logistics and Transportation Review, Vol 125, pp. 366-387.

$\mathrm{Wu}, \mathrm{Z}$. and Jia, F. (2018), "Toward a theory of supply chain fields - understanding the institutional process of supply chain localization", Journal of Operations Management, Vol. 5859 , pp. 27-41.

Wu, Z., Ellram, L.M. and Schuchard, R. (2014), "Understanding the Role of Government and Buyers in Supplier Energy Efficiency Initiatives", Journal of Supply Chain Management, Vol. 50 No. 2, pp. 84-105.

Yang, Y. and $\mathrm{Xu}, \mathrm{X}$. (2015), "Post-disaster grain supply chain resilience with government aid", Transportation Research Part E: Logistics and Transportation Review, Vol. 76, pp. 139-159.

Yean, T.S. (2018), "Services Liberalization: Case of Logistics in Brunei", in Yean, T.S. and Das, S.B. (Eds.), Services Liberalization in ASEAN: Foreign Direct Investment in Logistics, ISEAS-Yusof Ishak Institute, Singapore, pp. 242 267.

Yousaf, S. and Xiucheng, F. (2018), "Halal culinary and tourism marketing strategies on government websites: A preliminary analysis", Tourism Management, Vol. 68, pp. 423-443.

Zailani, S., Iranmanesh, M., Aziz, A.A. and Kanapathy, K. (2017), "Halal logistics opportunities and challenges", Journal of Islamic Marketing, Vol. 8 No. 1, pp. 127-139.

Zailani, S., Iranmanesh, M., Aziz, A.A. and Kanapathy, K. (2017), "Halal Logistics Opportunities and Challenges", Journal of Islamic Marketing, Vol. 8 No. 1, pp. 127-139.

Zhang, Y., Feng, Z., Zhang, S. and Song, J. (2018), "The effects of service level on BOT transport project contract", Transportation Research Part E: Logistics and Transportation Review, Vol. 118, pp. 184-206.

Zhao, L., Zhao, Y., Hu, Q., Li, H. and Stoeter, J. (2018), "Evaluation of consolidation center cargo capacity and loctions for China railway express", Transportation Research Part E: Logistics and Transportation Review, Vol. 117 No. SI, pp. 58-81.

Zimmermann, R., D.F. Ferreira, L.M. and Carrizo Moreira, A. (2016), "The influence of supply chain on the innovation process: a systematic literature review", Supply Chain Management: An International Journal, Vol. 21 No. 3, pp. 289-304.

Zomorrodi, M., Fayezi, S., Lau, K.H. and McMurray, A. (2019), "Supply chain adaptations for the base-of-the-pyramid business: towards a theoretical model", International Journal of Physical Distribution \& Logistics Management, Vol. 49 No. 5, SI, pp. 599-624. 
Zulfakar, M.H., Chan, C. and Jie, F. (2018), "Institutional forces on Australian halal meat supply chain (AHMSC) operations", Journal of Islamic Marketing, Vol. 9 No. 1, pp. 80-98.
Zulfakar, M.H., Chan, C. and Jie, F. (2018), "Institutional Forces on Australian Halal Meat Supply Chain (AHMSC) Operations", Journal of Islamic Marketing, Vol. 9 No. 1, pp. 80-98.

Mohamed Syazwan Ab Talib is an Assistant Professor of Logistics Management at the UBD School of Business and Economics, Universiti Brunei Darussalam. He holds a PhD in Management from Universiti Teknologi Malaysia, an MBA from Universiti Selangor and a BBA from Universiti Teknologi MARA. He was a Senior Lecturer in Marketing at Azman Hashim International Business School, Universiti Teknologi Malaysia and formerly a Lecturer in Logistics Management at the Faculty of Business and Information Science, UCSI University. His research and teaching focus primarily on logistics and supply chain management with specialisation on halal principles, distribution, and standards.

Li Li Pang is a Lecturer at the Universiti Brunei Darussalam's School of Business and Economics (UBDSBE). She was formerly at UBD's Institute of Policy Studies (IPS) and was one of the Coordinators of the Executive Development Programme for Senior Government Officers and Middle Management Officers (EDPSGO and EDPMMO) at the Institute of Leadership, Innovation and Advancement (ILIA), Universiti Brunei Darussalam. Dr Pang teaches public policy and governance issues, and her current research interests focus on local governance and public sector improvements. She holds an MSc in Public Policy from the University of Bristol, UK and PhD (Management) from Monash University, Australia.

Nur Atiqah Md Said is Finance Officer at the Treasury Department, Ministry of Finance and Economy, Brunei Darussalam, and a PhD (Management) candidate at UBD School of Business and Economics under the supervision of Dr Mohamed Syazwan Ab Talib. She was formerly an Inspection Officer (Logistics) at the Halal Food Control Division, Ministry of Religious Affairs, Brunei Darussalam. She holds a Master of Logistics and a Bachelor of Business from Universiti Brunei Darussalam. Nur Atiqah actively involves in research and training related to logistics, halal standards, information systems, and capacity building. 
APPENDIX 1: REVIEW RESULTS

\begin{tabular}{|c|c|c|c|c|c|c|c|c|c|}
\hline \multirow{2}{*}{ Author (year) } & \multirow{2}{*}{ Country } & \multirow{2}{*}{ Field of Study } & \multirow{2}{*}{ Source } & \multicolumn{6}{|c|}{ Strategic Measures } \\
\hline & & & & $\mathrm{RG}$ & FS & IN & ED & LB & EX \\
\hline Acar and Kaya (2019) & Turkey & Relief logistics & $\mathrm{JOM}$ & & & $\checkmark$ & & & \\
\hline Acimovic and Goentzel (2016) & Unspecified & Relief logistics & JOM & & & $\checkmark$ & & & \\
\hline Albalate and Bel (2010) & Various & Public transportation & TRE & $\checkmark$ & $\checkmark$ & & & & $\checkmark$ \\
\hline Bai et al. (2016) & China & Supply chain governance & JOM & $\checkmark$ & & & & & $\checkmark$ \\
\hline Bajec et al. (2015) & Slovenia & Green logistics & IJLM & $\checkmark$ & & & & & $\checkmark$ \\
\hline Bashir et al. (2019) & South Korea & Halal supply chain & JIMA & $\checkmark$ & $\checkmark$ & & $\checkmark$ & & $\checkmark$ \\
\hline Bhakoo and Choi (2013) & Australia & Healthcare supply chain & JOM & $\checkmark$ & $\checkmark$ & $\checkmark$ & $\checkmark$ & & $\checkmark$ \\
\hline Bolumole et al. (2015) & Various & Logistics hub/cluster & JBL & $\checkmark$ & $\checkmark$ & $\checkmark$ & & & \\
\hline Cai et al. (2010) & China & Supply chain integration & JOM & $\checkmark$ & $\checkmark$ & $\checkmark$ & & & $\checkmark$ \\
\hline Cantor and Terle (2010) & USA & Transportation Safety & IJPDLM & $\checkmark$ & & $\checkmark$ & & & $\checkmark$ \\
\hline Cantor et al. (2011) & USA & Commercial transportation & JBL & $\checkmark$ & & $\checkmark$ & & & $\checkmark$ \\
\hline Chang and $\mathrm{Wu}(2015)$ & Taiwan & Supply chain security & IJPDLM & $\checkmark$ & $\checkmark$ & & $\checkmark$ & & $\checkmark$ \\
\hline Chen and Wang (2016) & Unspecified & Transport mode selection & TRE & $\checkmark$ & & & & & $\checkmark$ \\
\hline Choi and Luo (2019) & Unspecified & Fashion supply chain & TRE & & $\checkmark$ & & & & \\
\hline Davis and Friske (2013) & USA and Canada & Cross-border logistics & JBL & $\checkmark$ & & $\checkmark$ & & & $\checkmark$ \\
\hline Dobrzykowski (2019) & USA & Healthcare supply chain & JSCM & $\checkmark$ & $\checkmark$ & $\checkmark$ & & & \\
\hline Dube et al. (2016) & Various & Relief logistics & $\mathrm{JOM}$ & $\checkmark$ & $\checkmark$ & $\checkmark$ & & & \\
\hline Dubey et al. (2018) & Various & Relief logistics & IJLM & & $\checkmark$ & $\checkmark$ & $\checkmark$ & & \\
\hline Dwivedi et al. (2017) & India & Automotive technology & IJPDLM & $\checkmark$ & $\checkmark$ & & $\checkmark$ & & $\checkmark$ \\
\hline Eckerd and Girth (2017) & USA & Risk management & JSCM & & & $\checkmark$ & & & \\
\hline Ehrgott et al. (2013) & USA and Germany & Sustainable supply chain & JBL & $\checkmark$ & & & & & $\checkmark$ \\
\hline Feng et al. (2012) & UK and China & Port performance & IJPDLM & $\checkmark$ & $\checkmark$ & $\checkmark$ & & & \\
\hline Gattiker and Carter (2010) & Unspecified & Environmental supply chain & $\mathrm{JOM}$ & $\checkmark$ & & & & & \\
\hline Gligor et al. (2018) & Vietnam & Cold supply chain & IJLM & $\checkmark$ & $\checkmark$ & $\checkmark$ & $\checkmark$ & & $\checkmark$ \\
\hline Goh (2019) & Various & Warehousing & IJPDLM & $\checkmark$ & $\checkmark$ & & & & \\
\hline Grainger and Morini (2019) & UK and Brazil & Cross-border logistics & IJLM & & & & & & \\
\hline Gualandris and Klassen (2018) & Unspecified & Supply network & JSCM & $\checkmark$ & & $\checkmark$ & & & \\
\hline Guerrero et al. (2013) & Unspecified & Environmental logistics & TRE & & $\checkmark$ & & & & \\
\hline Hafezalkotob (2017) & Iran & Green supply chain & TRE & $\checkmark$ & $\checkmark$ & & & & $\checkmark$ \\
\hline Hall and Matos (2010) & Brazil & Sustainable supply chain & IJPDLM & $\checkmark$ & $\checkmark$ & & & & $\checkmark$ \\
\hline Harland et al. (2019) & Various & Procurement & JSCM & $\checkmark$ & $\checkmark$ & & & & \\
\hline Harrod (2013) & Unspecified & Rail transportation & TRE & & $\checkmark$ & $\checkmark$ & & $\checkmark$ & \\
\hline Hausman et al. (2010) & China and USA & Cross-border logistics & JSCM & $\checkmark$ & & & & & $\checkmark$ \\
\hline Heaslip and Kovács (2019) & Ireland & Relief logistics & IJLM & & $\checkmark$ & $\checkmark$ & & & \\
\hline Huang et al. (2015) & Taiwan & Reverse logistics & IJPDLM & $\checkmark$ & & & & & $\checkmark$ \\
\hline Jacobs and Singhal (2017) & Bangladesh & Supply chain governance & $\mathrm{JOM}$ & $\checkmark$ & & & & & $\checkmark$ \\
\hline
\end{tabular}


$\mathrm{Ab}$ Talib, et al: What Can the Brunei Government Do to Encourage Halal Logistics Adoption: Lessons from the Literature Operations and Supply Chain Management 14(3) pp. $301-319$ (C) 2021

\begin{tabular}{|c|c|c|c|c|c|c|c|c|c|}
\hline \multirow{2}{*}{ Author (year) } & \multirow{2}{*}{ Country } & \multirow{2}{*}{ Field of Study } & \multirow{2}{*}{ Source } & \multicolumn{6}{|c|}{ Strategic Measures } \\
\hline & & & & $\mathrm{RG}$ & FS & IN & ED & LB & EX \\
\hline Kang et al. (2012) & Taipei & Public-private partnership & TRE & & $\checkmark$ & $\checkmark$ & & & \\
\hline Kang et al. (2013) & Unspecified & Public-private partnership & TRE & & $\checkmark$ & $\checkmark$ & & & \\
\hline Kundu and Sheu (2019) & China and Germany & Transport mode selection & TRE & & $\checkmark$ & & & & \\
\hline Lai et al. (2018) & China & Big data analytics & IJLM & $\checkmark$ & $\checkmark$ & & & & $\checkmark$ \\
\hline Li et al. (2018) & China & Transport network & TRE & $\checkmark$ & $\checkmark$ & $\checkmark$ & $\checkmark$ & & \\
\hline Li et al. (2019) & Unspecified & Infrastructure provision & TRE & $\checkmark$ & $\checkmark$ & $\checkmark$ & & $\checkmark$ & \\
\hline Li and Cai (2017) & Unspecified & Public-private partnership & TRE & & $\checkmark$ & & & & \\
\hline Lu and Meng (2017) & Unspecified & Public-private partnership & TRE & $\checkmark$ & $\checkmark$ & & & & \\
\hline McKinnon (2010) & Unspecified & Environmental supply chain & IJPDLM & $\checkmark$ & $\checkmark$ & & & & \\
\hline Min and Ahn (2017) & USA & Mass transit system & JBL & $\checkmark$ & $\checkmark$ & & & & $\checkmark$ \\
\hline Min et al. (2017) & USA & Mass transit system & IJLM & & $\checkmark$ & $\checkmark$ & & & \\
\hline Mittal et al. (2018) & India & Petroleum supply chain & IJLM & $\checkmark$ & $\checkmark$ & & & & \\
\hline Mogale et al. (2018) & India & Supply network & TRE & & & $\checkmark$ & & & \\
\hline Ngah et al. (2015) & Malaysia & Halal warehousing & JIMA & $\checkmark$ & $\checkmark$ & & & & $\checkmark$ \\
\hline Nguyen and Kim (2019) & Vietnam & Quality Management & JOM & $\checkmark$ & & & & & $\checkmark$ \\
\hline Niu et al. (2017) & China & Fashion supply chain & TRE & $\checkmark$ & $\checkmark$ & & & & $\checkmark$ \\
\hline Niu and Zhang (2013) & Unspecified & Public-private partnership & TRE & $\checkmark$ & $\checkmark$ & $\checkmark$ & & $\checkmark$ & \\
\hline Oum et al. (2013) & Japan & Multimodal transport & TRE & & & $\checkmark$ & & & \\
\hline Pålsson et al. (2017) & Sweden & High-capacity vehicles & IJPDLM & $\checkmark$ & $\checkmark$ & $\checkmark$ & & & $\checkmark$ \\
\hline Park et al. (2018) & Unspecified & Port management & TRE & $\checkmark$ & & $\checkmark$ & & & \\
\hline Paul and Wang (2015) & USA & Relief logistics & TRE & & & & & & $\checkmark$ \\
\hline Randall et al. (2011) & USA & Performance-based logistics & IJLM & & & & & & $\checkmark$ \\
\hline Rivera et al. (2014) & USA & Logistics cluster & IJPDLM & $\checkmark$ & & $\checkmark$ & & & $\checkmark$ \\
\hline Rahman et al. (2018) & Malaysia & Halal warehousing & JIMA & $\checkmark$ & $\checkmark$ & & $\checkmark$ & & $\checkmark$ \\
\hline Rotchanakitumnuai (2013) & Thailand & Procurement & IJPDLM & $\checkmark$ & & & & & \\
\hline Scholten et al. (2010) & Various & Relief logistics & IJPDLM & $\checkmark$ & & $\checkmark$ & & & \\
\hline Sheu (2011) & Taiwan & Green supply chain & TRE & & $\checkmark$ & & & & \\
\hline Sheu (2016) & Taiwan & Relief supply chain & TRE & & & $\checkmark$ & & & $\checkmark$ \\
\hline Sirilertsuwan et al. (2018) & Unspecified & Sustainable supply chain & IJLM & $\checkmark$ & & $\checkmark$ & $\checkmark$ & & $\checkmark$ \\
\hline Song et al. (2018) & China & Supply chain integration & IJLM & & $\checkmark$ & & & & \\
\hline Spring et al. (2017) & UK & Operation management & JOM & $\checkmark$ & $\checkmark$ & & $\checkmark$ & $\checkmark$ & \\
\hline Srivastava et al. (2015) & India & Food supply chain & IJLM & $\checkmark$ & & & & & \\
\hline Storer et al. (2014) & Australia & Food supply chain & IJLM & $\checkmark$ & & & & & \\
\hline Swanson and Smith (2013) & USA & Relief logistics & JBL & & & $\checkmark$ & & & \\
\hline Talib and Hamid (2014) & Malaysia & Halal logistics & JIMA & $\checkmark$ & & $\checkmark$ & $\checkmark$ & & $\checkmark$ \\
\hline Talib et al. (2015) & Unspecified & Halal supply chain & JIMA & $\checkmark$ & & $\checkmark$ & $\checkmark$ & & $\checkmark$ \\
\hline Talib et al. (2016b) & Unspecified & Logistics performance & JIMA & $\checkmark$ & & $\checkmark$ & $\checkmark$ & & $\checkmark$ \\
\hline Tan (2012) & China & Road Infrastructure & TRE & & $\checkmark$ & $\checkmark$ & & & \\
\hline Tokar and Swink (2019) & Unspecified & Supply chain governance & JSCM & $\checkmark$ & & & & $\checkmark$ & \\
\hline
\end{tabular}


$\mathrm{Ab}$ Talib, et al.: What Can the Brunei Government Do to Encourage Halal Logistics Adoption: Lessons from the Literature

Operations and Supply Chain Management 14(3) pp. $301-319$ (C) 2021

\begin{tabular}{|c|c|c|c|c|c|c|c|c|c|}
\hline \multirow{2}{*}{ Author (year) } & \multirow{2}{*}{ Country } & \multirow{2}{*}{ Field of Study } & \multirow{2}{*}{ Source } & \multicolumn{6}{|c|}{ Strategic Measures } \\
\hline & & & & $\mathrm{RG}$ & $\mathrm{FS}$ & IN & ED & LB & EX \\
\hline Tong et al. (2018) & China & Corporate social responsibility & JOM & $\checkmark$ & $\checkmark$ & & & & $\checkmark$ \\
\hline Tu et al. (2018) & Indonesia & Shipping network & TRE & $\checkmark$ & & & & & $\checkmark$ \\
\hline Voss and Williams (2013) & USA & Public-private partnership & JBL & & & & & & $\checkmark$ \\
\hline Wang et al. (2016) & China & Supplier-buyer relationship & JOM & $\checkmark$ & $\checkmark$ & & & & \\
\hline Wang et al. (2018) & Japan & Relief supply chain & IJLM & & & $\checkmark$ & & & \\
\hline Wang et al. (2019) & China & Closed-loop supply chain & TRE & $\checkmark$ & $\checkmark$ & & & & \\
\hline Wu and Jia (2018) & China & Supply chain localization & JOM & $\checkmark$ & $\checkmark$ & & & & \\
\hline Wu et al. (2014) & China & Supplier-buyer relationship & JSCM & $\checkmark$ & & & $\checkmark$ & & $\checkmark$ \\
\hline Yang and $\mathrm{Xu}(2015)$ & China & Supply chain resilience & TRE & $\checkmark$ & $\checkmark$ & & & & $\checkmark$ \\
\hline Zailani et al. (2017) & Malaysia & Halal logistics & JIMA & $\checkmark$ & $\checkmark$ & & & & $\checkmark$ \\
\hline Zhang et al. (2018) & Unspecified & Public-private partnership & TRE & $\checkmark$ & & & & & \\
\hline Zhao et al. (2018) & China & Terminal location & TRE & $\checkmark$ & $\checkmark$ & & & & \\
\hline Zomorrodi et al. (2019) & Australia & Supply chain adaptations & IJPDLM & $\checkmark$ & & $\checkmark$ & $\checkmark$ & & $\checkmark$ \\
\hline Zulfakar et al. (2018) & Australia & Halal meat supply chain & JIMA & $\checkmark$ & & & & & $\checkmark$ \\
\hline
\end{tabular}

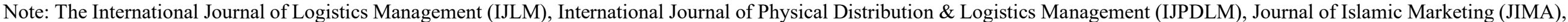

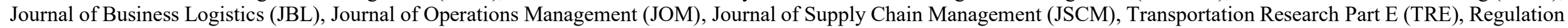
(RG), Fiscal Support (FS), Infrastructure and Assets (IN), Education and Research (ED), Liberalisation (LB), and Exhortation (EX). 